\title{
8. ALTERATION OF THE UPPER OCEANIC CRUST: MINERALOGY AND PROCESSES IN DEEP SEA DRILLING PROJECT HOLE 504B, LEG 831
}

\author{
Jeffrey C. Alt, Department of Marine Geology and Geophysics, Rosenstiel School of Marine and Atmospheric \\ Science, University of Miami \\ Christine Laverne, Laboratoire de Geologie, Faculté des Sciences et Techniques BPW \\ and \\ Karlis Muehlenbachs, Department of Geology, University of Alberta²
}

\begin{abstract}
Leg 83 of the Deep Sea Drilling Project has deepened Hole 504B to over $1 \mathrm{~km}$ into basement, $1350 \mathrm{~m}$ below the seafloor (BSF). The hole previously extended through $274.5 \mathrm{~m}$ of sediment and $561.5 \mathrm{~m}$ of pillow basalts altered at low temperature $\left(\leq 100^{\circ} \mathrm{C}\right)$, to $836 \mathrm{~m}$ BSF. Leg 83 drilling penetrated an additional $10 \mathrm{~m}$ of pillows, a $209-\mathrm{m}$ transition zone, and $295 \mathrm{~m}$ into a sheeted dike complex. Leg 83 basalts (836-1350 m BSF) generally contain superimposed greenschist and zeolite-facies mineral parageneses.

Alteration of pillows and dikes from 836 to $898 \mathrm{~m}$ BSF occurred under reducing conditions at low water/rock ratios, and at temperatures probably greater than $100^{\circ} \mathrm{C}$. Evolution of fluid composition resulted in the formation of (1) clay minerals, followed by (2) zeolites, anhydrite, and calcite.

Alteration of basalts in the transition zone and dike sections (898-1350 m BSF) occurred in three basic stages, defined by the opening of fractures and the formation of characteristic secondary minerals. (1) Chlorite, actinolite, pyrite, albite, sphene, and minor quartz formed in veins and host basalts from partially reacted seawater (Mg-bearing, locally metal-and Si-enriched) at temperatures of at least $200-250^{\circ} \mathrm{C}$. (2) Quartz, epidote, and sulfides formed in veins at temperatures of up to $380^{\circ} \mathrm{C}$, from more evolved (Mg-depleted, metal-, Si-, and ${ }^{18} \mathrm{O}$-enriched) fluids. (3) The last stage is characterized by zeolite formation: (a) analcite and stilbite formed locally, possibly at temperatures less than $200^{\circ} \mathrm{C}$ followed by (b) formation of laumontite, heulandite, scolecite, calcite, and prehnite from solutions depleted in $\mathrm{Mg}$ and enriched in $\mathrm{Ca}$ and ${ }^{18} \mathrm{O}$, at temperatures of up to $250^{\circ} \mathrm{C}$. The presence of small amounts of anhydrite locally may be due to ingress of relatively unaltered seawater into the system during Stage 3.

Alteration was controlled by the permeability of the crust and is characterized by generally incomplete recrystallization and replacement reactions among secondary minerals. Secondary mineralogy in the host basalts is strongly controlled by primary mineralogy.

The alteration of Leg 83 basalts can be interpreted in terms of an evolving hydrothermal system, with (a) changes in solution composition because of reaction of seawater fluids with basalts at high temperatures; (b) variations in permeability caused by several stages of sealing and reopening of cracks; and (c) a general cooling of the system, caused either by the cooling of a magma chamber beneath the spreading center and/or the movement of the crust away from the heat source. The relationship of the high-temperature alteration in the transition zone and dike sections to the low-temperature alteration in the overlying pillow section remains uncertain.
\end{abstract}

\section{INTRODUCTION}

Basalt-seawater interaction in submarine hydrothermal systems is an important process in the oceans affecting the chemical composition of seawater and the crust, magnetic properties and seismic structure of the crust, and resulting in seafloor metal sulfide deposits (e.g., Houtz and Ewing, 1976: Edmond et al., 1979; RISE Project Group, 1980; Harrison, 1981). An understanding of how submarine hydrothermal systems work is essential to interpretation of their effects on the previously mentioned properties.

DSDP Hole 504B is the deepest drilled basement section in the oceanic crust. Drilling penetrated into a sheeted dike complex and recovered the first in situ basalts containing greenschist facies mineral parageneses. These

\footnotetext{
1 Anderson, R. N. , Honnorez, J. , Becker, K. , et al., Init. Repts., DSDP, 83: Washington (U.S. Govt. Printing Office).

2 Addresses: (Alt, present address) Department of Earth and Planetary Sciences, Washington University, Campus Box 1169, St. Louis, MO 63130; (Laverne) Laboratoire de Geologie, Faculté des Sciences et Techniques BPW, 3038 SFAX, Tunisia; (Muehlenbachs) Department of Geology, University of Alberta, Edmonton, Alberta, Canada T6G 2E3.
}

cores thus provide a unique set of samples to study the alteration of the oceanic crust. This chapter presents a preliminary description of alteration effects and data on the mineralogy, oxygen and carbon isotopic composition, and occurrence of alteration products in the Leg $83 \mathrm{sec}-$ tion of Hole 504B, along with some new data for the Leg 69 and 70 sections. The purpose of this work is to determine the sequence and conditions of alteration in Leg 83 basalts to further our understanding of submarine hydrothermal systems.

\section{SITE 504}

Site 504 is located in 5.9-m.y.-old crust south of the Costa Rica Rift in eastern Pacific. The hole reaches 1.35 $\mathrm{km}$ into the oceanic crust (Fig. 1), penetrating $274.5 \mathrm{~m}$ of sediment; $571.5 \mathrm{~m}$ of pillow and massive basalts and breccias; a 209-m transition zone comprising pillows, massive flows, and dikes; and $295 \mathrm{~m}$ of dikes and massive units that are interpreted to be part of a sheeted dike complex. Details of the lithostratigraphy are given in Cann, Langseth, Honnorez, Von Herzen, White, et al., (1983) and Adamson (this volume). Measured heat flow 


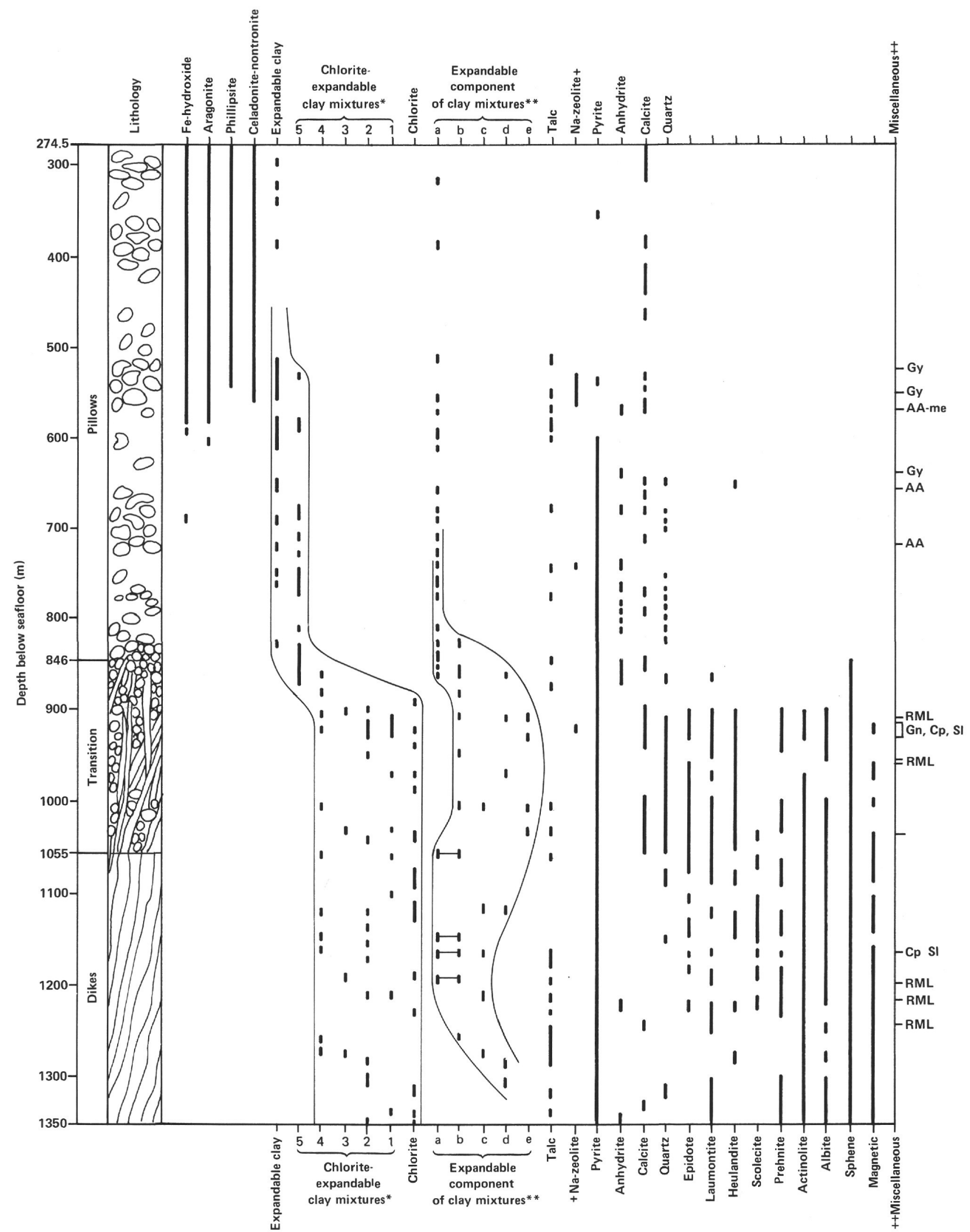

Figure 1. Distribution of secondary minerals with depth in Hole 504B. ${ }^{+}$includes analcite, stilbite, thompsonite, and natrolite. ${ }^{++}$Gy $=$gyrolite, $\mathrm{AA}=$ aegerine augite, $\mathrm{Me}=$ melanite, $\mathrm{RML}=$ regular-mixed-layer chlorite-smectite, $\mathrm{Gn}=$ galena, $\mathrm{Cp}=$ chalcopyrite, $\mathrm{Sl}=$ sphalerite. ${ }^{*}$ mixtures range from chlorite-rich (Type 1$)$ to expandable layer-rich (Type 5; see text). ${ }^{* *}$ mixtures range from pure smectite (a) to pure vermiculite (e; see text). Data from Honnorez et al., 1983, and this chapter. 
at the site falls close to the theoretical conductive cooling curve for ocean crust, and temperatures in the hole fall on a conductive gradient ranging from $60^{\circ} \mathrm{C}$ at the basement/sediment interface to $160^{\circ} \mathrm{C}$ at the bottom of the hole (Becker et al., 1983; this volume).

Preliminary studies of the mineralogy and chemistry of altered basalts from 274.5 to $835.5 \mathrm{~m}$ below the seafloor (BSF) have been carried out (Cann, Langseth, Honnorez, Von Herzen, White, et al., 1983). Honnorez et al. (1983) divided this section into three alteration zones (Fig. 1). An upper alteration zone $(274.5-584.5 \mathrm{~m})$ is characterized by the presence of iron hydroxides and celadonite-nontronite filling voids and replacing olivine in oxidation halos around cracks, with saponite replacing olivine and filling voids throughout the basalts. Phillipsite, calcite and rare anhydrite also occur. Chemical changes involved oxidation, hydration, gain of potassium, and loss of silica. The lower alteration zone (584.5-835.5 m) is characterized by the presence of saponite and pyrite, as well as minor calcite, quartz, $\mathrm{Na}$ (and $\mathrm{Na}-\mathrm{Ca}$ ) zeolites, and anhydrite. Basalts from this zone have lost $\mathrm{Ca}$ and gained $\mathrm{Mg}$. A zeolite alteration zone occurs superimposed on the upper alteration zone from 528.5 to $563 \mathrm{~m}$. This zone is characterized by the presence of $\mathrm{Na}$ (and $\mathrm{Na}-\mathrm{Ca}$ ) zeolites in veins and in wall-rock alteration zones and by uptake of $\mathrm{Na}, \mathrm{K}, \mathrm{Mg}, \mathrm{Ca}, \mathrm{CO}_{2}$, and $\mathrm{H}_{2} \mathrm{O}^{+}$.

Superimposition of stages of oxidative and anoxic alteration processes are interpreted to be responsible for the upper alteration zone, whereas alteration in the lower zone occurred under anoxic conditions either with seawater at low water/rock ratios or with seawater that had previously reacted with basalt. The zeolite zone alteration remains somewhat of a problem, but may be related to localized circulation of fluids originating from reactions eleswhere in the crust. Alteration throughout the pillow section (274.5-835.5 m) probably took place at temperatures below about $100^{\circ} \mathrm{C}$, although the zeolite zone may have formed at slightly higher temperatures.

\section{METHODS}

In addition to samples studied on shipboard, close to 200 samples were studied using thin sections in transmitted and reflected light and by X-ray diffraction and electron microprobe. X-ray diffraction was preformed using a Philips diffractometer with carbon crystal monochromator and CuKo radiation and Debye-Scherrer and Gandolifi cameras with Mn-filtered Fe-radiation. Microprobe analyses were made on the same samples identified by X-ray diffraction whenever possible. Microprobe analyses were made using the 9-channel ARL SEMQ microprobe at the Smithsonian Institution, Washington, D.C., and the Automated Camebax instrument at the Centre Océanologique de Bretagne, Brest, France. Operating conditions for the ARL instrument were $20 \mathrm{kV}$ accelerating voltage; $0.025 \mu \mathrm{A}$ specimen current; $20 \mu \mathrm{m}$ spot size; 10-s counting time, and those for the Camebax instrument were $15 \mathrm{kV}$ accelerating voltage $0.015 \mu \mathrm{A}$ specimen current, $1 \mu \mathrm{m}$ spot size; 6-s counting time.

\section{SECONDARY MINERALOGY}

\section{Actinolite}

Actinolite is rare above $967 \mathrm{~m}$; it was identified by X-ray diffraction in bulk rock samples from 906 to $912 \mathrm{~m}$ below seafloor (BSF) and optically in several samples where it occurs as needles and prisms projecting inward from the walls of clay mineral pseudomorphs after olivine phenocrysts and replacing the edge of a clinopyroxene phenocryst.

Actinolite occurs in varying amounts below $967 \mathrm{~m} \mathrm{BSF}$, most commonly as pleochroic green to yellow green, fibrous reaction rims or overgrowths on clinopyroxene (Plate 1, Fig. 3). Actinolite also frequently occurs as fibers intergrown with chlorite and occasionally quartz and epidote in veins. In one sample (Sample 504B-92-1, 128$131 \mathrm{~cm}$ ) sub- to euhedral prismatic actinolite crystals up to $250 \times 100 \mu \mathrm{m}$ occur in a vein with abundant actinolite fibers, quartz, and chlorite.

Leg 83 amphibole compositions range from actinolites and ferroactinolites through actinolitic and ferroactinolitic hornblendes, to minor amounts of magnesiohornblendes (Table 1, Fig. 2). No systematic difference in occurrence was observed among the various compositions of amphiboles. Published analyses of amphiboles from other submarine basalts and diabases are variable, but are restricted to actinolite compositions (data in Mottl, 1983). The lower Si values of some of the Leg 83 amphiboles may in part result from analytical difficulties because of the presence of unobserved Al-rich chlorite intergrown with the fibrous amphiboles. However, the presence of intergrown chlorite cannot explain the higher $\mathrm{Fe}$ contents of the Leg 83 amphiboles relative to other published analyses from similar rocks since the Leg 83 am-

Table 1. Microprobe analyses of actinolite and clinopyroxene, Hole 504B.

\begin{tabular}{|c|c|c|c|c|c|}
\hline & \multicolumn{5}{|c|}{ Analysis } \\
\hline & 1 & 2 & 3 & 4 & 5 \\
\hline $\mathrm{SiO}_{2}$ & 53.10 & 52.08 & 53.41 & 48.70 & 51.09 \\
\hline $\mathrm{TiO}_{2}$ & 0.13 & 0.29 & 0.07 & 0.46 & 0.34 \\
\hline $\mathrm{Al}_{2} \mathrm{O}_{3}$ & 2.58 & 2.95 & 2.58 & 3.31 & 4.35 \\
\hline $\mathrm{FeOT}$ & 16.59 & 4.91 & 14.95 & 28.52 & 15.53 \\
\hline $\mathrm{MnO}$ & 0.52 & 0.20 & 0.42 & 0.51 & 0.42 \\
\hline $\mathrm{MgO}$ & 12.38 & 17.89 & 13.50 & 8.13 & 14.82 \\
\hline $\mathrm{Cr}_{2} \mathrm{O}_{3}$ & $\mathrm{n}$ & $\mathrm{n}$ & $\mathrm{n}$ & $\mathrm{n}$ & $\mathrm{n}$ \\
\hline $\mathrm{CaO}$ & 12.81 & 20.93 & 13.02 & 7.29 & 10.14 \\
\hline $\mathrm{Na}_{2} \mathrm{O}$ & 0.22 & 0.20 & 0.26 & 0.61 & 0.66 \\
\hline $\mathrm{K}_{2} \mathrm{O}$ & 0.02 & 0.00 & 0.02 & 0.06 & 0.03 \\
\hline Total & 98.35 & 99.46 & 98.23 & 97.59 & 97.37 \\
\hline $\mathrm{Si}$ & 7.72 & & 7.71 & 7.42 & 7.36 \\
\hline $\mathrm{Ti}$ & 0.01 & & - & 0.05 & 0.04 \\
\hline Al & 0.44 & & 0.44 & 0.60 & 0.74 \\
\hline $\mathrm{FeT}$ & 2.02 & & 1.80 & 3.64 & 1.87 \\
\hline $\mathrm{Mn}$ & 0.06 & & 0.05 & 0.07 & 0.05 \\
\hline Mg & 2.68 & & 2.90 & 1.85 & 3.18 \\
\hline $\mathrm{Cr}$ & $\mathrm{n}$ & $\mathrm{n}$ & $\mathrm{n}$ & $\mathrm{n}$ & $\mathrm{n}$ \\
\hline $\mathrm{Ca}$ & 2.00 & & 2.01 & 1.19 & 1.57 \\
\hline $\mathrm{Na}$ & 0.06 & & 0.07 & 0.18 & 0.18 \\
\hline K & - & & - & 0.01 & - \\
\hline Total & 14.99 & & 14.98 & 15.01 & 14.99 \\
\hline
\end{tabular}

Note: Oxides given as wt. \%. Structural formulas calculated based on 23 oxygens. Dashes indicate undetected elements, $\mathrm{n}=$ not analyzed. $1=$ Actinolite replacing olivine phenocryst; Sample $79-2,62-66 \mathrm{~cm} .2$ = Clinopyroxene, partly replaced by actinolite (analysis 3 ) along cracks and around edges; Sample 81-1, 83-86 cm. $3=$ Actinolite replacing clinopyroxene phenocryst (analysis 2); Sample 81-1, 83-86 cm. 4 = Ferroactinolite replacing clinopyroxene; Sample $127-1,109-112 \mathrm{~cm} .5=$ Actinolite replacing clinopyroxene; Sample 139-1, 29-33 cm. 


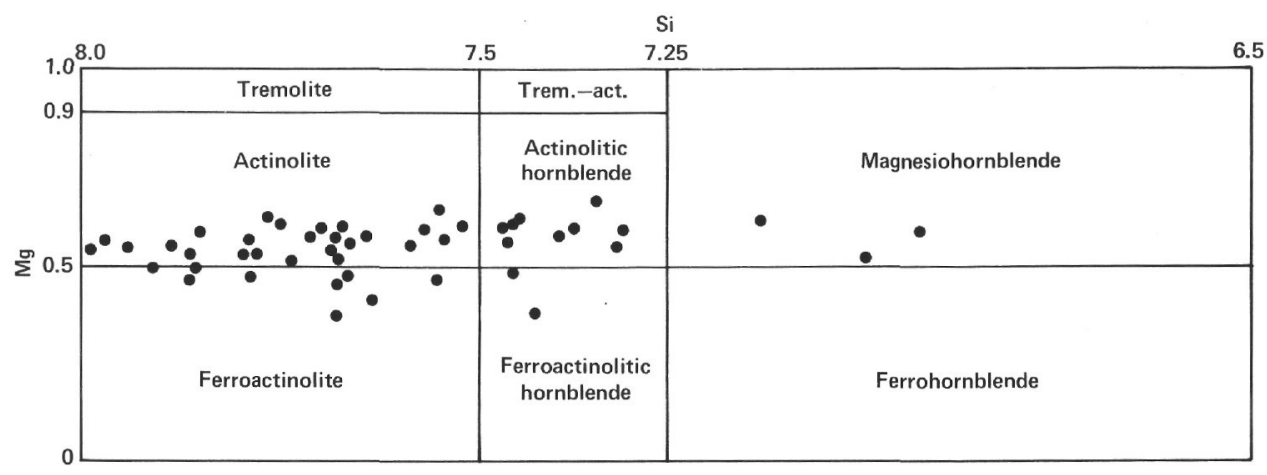

Figure 2. Microprobe analyses of Leg 83 amphiboles plotted on amphibole classification diagram (after Leake, 1978).

phiboles do not exhibit the trend of changing $\mathrm{Mg}$ value with decreasing Si that would be expected if intergrown Fe-rich chlorite were the source of the Fe enrichment.

\section{Analcite}

Analcite was identified in three Leg 83 samples. In Sample 504B-80-2, 90-97 cm it occurs in a vein with clay minerals, quartz, pyrite, sphalerite, chalocopyrite, calcite, prehnite, and laumontite. The analcite is corroded and replaced by Na-rich laumontite around its perimeter (Plate 2, Figs. 1, 2).

Analcite occurs in a vein of Sample 504B-80-3, 107$110 \mathrm{~cm}$ as subisotropic crystals in contact with heulanditeepistilbite. Euhedral grains of quartz occur within the analcite and heulandite-epistilbite. Analcite was also identified by $\mathrm{X}$-ray diffraction in a vein with laumontite and quartz in Sample 504B-80-2, 63-67 cm, but was not observed in thin section.

Leg 83 analcite compositions given in Table 2 are slightly lower in $\mathrm{Al}_{2} \mathrm{O}_{3}$ than analyses given by Deer et al., (1964) and analcites from the pillow section of Hole 504B (Honnorez et al., 1983). Cation totals are also somewhat low, possibly because of the volatilization of alkalis under the electron beam during microprobe analysis.

\section{Anhydrite}

Anhydrite has been identified in 12 samples from three different locations on the Leg 83 section (Fig. 1). It is less abundant than the shipboard party originally thought: aboard ship it was confused with laumontite, which has a similar habit and occurrence in hand specimen.

Anhydrite occurs as euhedral prisms, up to $3 \mathrm{~mm}$ in length, generally at the center of clay mineral veins. Radiating clusters of anhydrite prisms occur in clay veins from 846 to $864 \mathrm{~m}$ BSF. Anhydrite occurs with laumontite in a vein in Sample 504B-139-1, 29-33 cm. In Sample 504B-141-1, 58-61 cm anhydrite is partly replaced by laumontite, and both phases are replaced by prehnite (Plate 3, Fig. 4).

\section{Calcite}

Calcite is a late-forming mineral that occurs as a filling for remaining space in quartz veins and in cross-cutting veinlets. It also occasionally partly replaces plagio-
Table 2. Microprobe analysis of analcite, Hole 504B.

\begin{tabular}{|c|c|c|}
\hline & \multicolumn{2}{|c|}{ Analysis } \\
\hline & 1 & 2 \\
\hline $\mathrm{SiO}_{2}$ & 58.77 & 54.54 \\
\hline $\mathrm{TiO}_{2}$ & 0.02 & - \\
\hline $\mathrm{Al}_{2} \mathrm{O}_{3}$ & 22.91 & 20.26 \\
\hline $\mathrm{FeO}(\mathrm{T})$ & - & 0.01 \\
\hline $\mathrm{MnO}$ & 0.01 & - \\
\hline $\mathrm{MgO}$ & 0.01 & 0.02 \\
\hline $\mathrm{Cr}_{2} \mathrm{O}_{3}$ & $\mathrm{n}$ & 0.02 \\
\hline $\mathrm{CaO}$ & 0.30 & 0.34 \\
\hline $\mathrm{Na}_{2} \mathrm{O}$ & 11.93 & 11.19 \\
\hline $\mathrm{K}_{2} \mathrm{O}$ & 0.03 & 0.09 \\
\hline Total & 93.98 & 86.49 \\
\hline $\mathrm{Si}$ & 2.07 & 2.09 \\
\hline $\mathrm{Ti}$ & - & - \\
\hline Al & 0.95 & 0.92 \\
\hline $\mathrm{Fe}(\mathrm{T})$ & - & - \\
\hline $\mathrm{Mn}$ & - & - \\
\hline $\mathrm{Mg}$ & - & - \\
\hline $\mathrm{Cr}$ & - & - \\
\hline $\mathrm{Ca}$ & 0.01 & 0.01 \\
\hline $\mathrm{Na}$ & 0.82 & 0.83 \\
\hline K & - & - \\
\hline Total & 3.86 & 3.85 \\
\hline $\begin{array}{c}\text { Note: Ox } \\
\% \% . S \\
\text { las } \\
\text { on } 6 \\
\text { indic } \\
\text { elem } \\
\text { analy } \\
\text { cite } \\
80-2, \\
\text { Anal } \\
\text { Sam } \\
110\end{array}$ & $\begin{array}{l}\text { des given } \\
\text { ructural f } \\
\text { alculated } \\
\text { xygens. I } \\
\text { te unde } \\
\text { nts, n } \\
\text { zed. } 1= \\
\text { vein; S } \\
91-97 \mathrm{~cm} \\
\text { ite in } \\
\text { le } 80-3 \text {, } \\
\text { n. }\end{array}$ & $\begin{array}{l}\text { as wt. } \\
\text { ormu- } \\
\text { based } \\
\text { Dashes } \\
\text { tected } \\
=\text { not } \\
\text { Anal- } \\
\text { ample } \\
2= \\
\text { vein; } \\
107-\end{array}$ \\
\hline
\end{tabular}

clase phenocrysts in minor amounts, although it is particularly abundant in Sample 504B-91-2, 54-59 cm, in wall rock adjacent to a calcite vein. Plagioclase and clinopyroxene are extensively replaced by calcite. Calcite occurs as clear, sparry crystals and is often twinned. Calcite distribution is shown in Figure 1, but it is especially abundant in the sulfide-rich stockwork zone (910$928 \mathrm{~m} \mathrm{BSF}$ ) and occurs in only minor amounts elsewhere. Calcites generally contain no detectable $\mathrm{Mg}$ as 
determined by microprobe (Table 3 ) and X-ray diffraction (Goldsmith et al., 1961), but contain up to $1 \mathrm{~mol} \%$ $\mathrm{Mn}$ in the stockwork-like zone (910-928 m BSF).

\section{Epidote}

Epidote occurs almost exclusively in veins as prismatic crystals up to $5 \mathrm{~mm}$ long, often in radiating aggregates, and intergrown frequently with quartz and occasionally with inclusions of actinolite (Plate 3, Fig. 1). Epidote is most commonly associated with quartz and later laumontite in breccias and reaches maximum abundance around $1003 \mathrm{~m}$ BSF. Two generations of epidote are occasionally observed: granular, fine-grained epidote is followed or cut by coarser grained prismatic epidote.

Epidote only rarely partly replaces igneous minerals, most often plagioclase in alteration halos around epidote + quartz veins.

Epidotes in Leg 83 basalts have typical epidote compositions with constant $\mathrm{CaO}$ contents (Table 4; Deer et al., 1964). Substitution of $\mathrm{Fe}^{3+}$ for $\mathrm{Al}$ varies slightly, even within a single crystal (Table 4, Analyses 3-5), but no consistent zonation was detected optically or by microprobe. No difference in composition was detected between the coarse- and fine-grained epidote generations.

\section{Secondary Feldspars}

Albite generally occurs replacing plagioclase to varying extents throughout the hole below $898 \mathrm{~m}$ BSF (Plate 1, Fig. 4). Albite only rarely occurs as colorless crystals in veins with chlorite, actinolite, quartz, heulandite, laumontite, and prehnite (Samples 504B-100-1, 14-18 cm; 504B-111-1, 104-107 cm; 504B-116-1, 106-110 cm; 504B$140-1,27-31 \mathrm{~cm})$. Compositions are typically albite (90$100 \% \mathrm{Ab})$, but range up to oligoclase $(80-90 \% \mathrm{Ab})$ in a few samples (Table 5).

Table 3. Selected microprobe analyses of calcites, Hole 504B.

\begin{tabular}{lccc}
\hline & \multicolumn{3}{c}{ Analysis } \\
\cline { 2 - 4 } & 1 & 2 & 3 \\
\hline $\mathrm{SiO}_{2}$ & 0.12 & - & - \\
$\mathrm{TiO}_{2}$ & 0.03 & 0.03 & - \\
$\mathrm{Al}_{2} \mathrm{O}_{3}$ & 0.02 & - & - \\
$\mathrm{FeO}(\mathrm{T})$ & 0.05 & - & - \\
$\mathrm{MnO}$ & 0.04 & 0.30 & 0.04 \\
$\mathrm{MgO}$ & 0.05 & - & - \\
$\mathrm{Cr}_{2} \mathrm{O}_{3}$ & $\mathrm{n}$ & 0.03 & 0.03 \\
$\mathrm{CaO}$ & 52.74 & 59.02 & 56.16 \\
$\mathrm{Na} 2 \mathrm{O}$ & 0.03 & - & - \\
$\mathrm{K}_{2} \mathrm{O}$ & 0 & 0.01 & - \\
Total & 53.08 & 59.40 & 56.23 \\
\end{tabular}

Note: Oxides given as wt. \%. Dashes indicate undetected elements, $\mathrm{n}=$ not analyzed. $1=$ Calcite in vein with clay minerals and anhydrite; Sample 73-2, $29-32 \mathrm{~cm} .2$ = Mn-rich calcite in quartz vein; Sample 82-1, $46-49 \mathrm{~cm} .3=$ Calcite in heulandite + laumonite vein Sample $90-3,120-123 \mathrm{~cm}$

\section{Heulandite-Epistilbite}

These two minerals commonly occur in veins in relatively small amounts, occasionally as small euhedral crystals intergrown with laumontite or as larger crystals making up millimeter-sized veins. Frequently heulandite also partly replaces quartz and plagioclase (Plate 3, Fig. 3).

Heulandite and epistilbite were not always distinguishable by X-ray diffraction because of the small amounts of material available and orientation effects in smear slides. Epistilbite was identified optically in Samples 504B$100-1,83-87 \mathrm{~cm}$; 504B-101-1, 134-136 cm; and 504B-104$2,48-55 \mathrm{~cm}$; the presence of heulandite was confirmed optically in Samples 504B-79-2, 62-66 cm; and 504B$81-1,134-138 \mathrm{~cm}$; in all other samples the two minerals were indistinguishable optically because the crystals were too small.

The chemical compositions (Table 6) of minerals identified as heulandite-epistilbite by X-ray diffraction are very close to heulandite compositions given by Deer et al., (1964), with high $\mathrm{Ca}$ contents (almost always >3.90) and relativley low $\mathrm{Na}+\mathrm{K}$ contents. In Sample 504B-80-1, $106-111 \mathrm{~cm}$, however, heulandite replacing quartz in a vein is $\mathrm{K}_{2} \mathrm{O}$-rich (Table 6, Analysis 1). Otherwise there is no significant difference among the compositions of heulandite-epistilbite occurring in veins, vugs, or as replacments of plagioclase and quartz.

\section{Laumontite}

Laumontite was identified by X-ray diffraction on shipboard, but subsequent shore-based study revealed that all laumontite had partially dehydrated to form leonhardite within about one month. Dehydration of laumontite results in decreased refractive indexes and $2 \mathrm{~V}$ angle; a slight change in cleavage angles also occurs, causing the crystals often to break into pieces (Coombs, 1952).

Laumontite is the most common zeolite and is found in varying amounts throughout most of the hole below $898 \mathrm{~m}$ BSF. It forms large, bladed crystals, occasionally in radiating aggregates, and occurs mostly as a late mineral in veins (Plate 3, Fig. 1). Quartz is occasionally partially to totally replaced by laumontite in veins (e.g., Sample 504B-80-1, 106-112 cm). Prehnite is commonly associated with laumontite in veins below $1130 \mathrm{~m}$ BSF. Laumontite also occasionally occurs in bulk rocks partly replacing plagioclase and filling primary void space (vugs).

Laumontites in Leg 83 basalts are relatively uniform in composition with very low $\mathrm{Na}$ and $\mathrm{K}$ contents (Table 7). However, laumontite replacing analcite in Sample 504B-80$2,90-97 \mathrm{~cm}$ is Na-rich in contrast to laumontite replacing quartz in the same sample (Plate 2; Table 7, Analyses 1,2$)$.

\section{Iron Oxides}

Magnetite is the most common Fe-oxide; it occurs almost ubiquitously in minor amounts as fine "dust" replacing clinopyroxene below $910 \mathrm{~m}$ BSF. Ferric oxidehydroxides are rarely associated with the magnetite replacing clinopyroxene. Magnetite locally replaces olivine, associated with chlorite-smectite mixtures, from 1081 to 
Table 4. Selected microprobe analyses of epidote, Hole 504B.

\begin{tabular}{|c|c|c|c|c|c|c|c|c|c|c|}
\hline & \multicolumn{10}{|c|}{ Analysis } \\
\hline & 1 & & 2 & & 3 & & 4 & & 5 & \\
\hline $\mathrm{SiO}_{2}$ & 38.45 & & 37.89 & & 38.25 & & 37.94 & & 37.75 & \\
\hline $\mathrm{TiO}_{2}$ & 0.02 & & 0.44 & & 0.15 & & 0.03 & & - & \\
\hline $\mathrm{Al}_{2} \mathrm{O}_{3}$ & 26.50 & & 22.98 & & 24.33 & & 27.34 & & 23.93 & \\
\hline $\mathrm{FeO}$ & 9.07 & & 12.27 & & 10.79 & & 7.29 & & 11.17 & \\
\hline $\mathrm{MnO}$ & 0.12 & & 0.20 & & 0.07 & & 0.04 & & - & \\
\hline $\mathrm{MgO}$ & - & & - & & - & & - & & - & \\
\hline $\mathrm{Cr}_{2} \mathrm{O}_{3}$ & 0.15 & & 0.09 & & - & & 0.02 & & 0.04 & \\
\hline $\mathrm{CaO}$ & 23.23 & & 23.89 & & 23.61 & & 23.49 & & 23.36 & \\
\hline $\mathrm{Na}_{2} \mathrm{O}$ & - & & 0.05 & & - & & - & & - & \\
\hline $\mathrm{K}_{2} \mathrm{O}$ & - & & - & & - & & - & & - & \\
\hline Total & 101.14 & & 97.81 & & 97.20 & & 99.73 & & 99.77 & \\
\hline $\mathrm{Si}$ & 2.998 & 3.000 & 2.990 & 3.000 & 3.014 & 3.014 & 2.9907 & 3.000 & 3.008 & 3.008 \\
\hline $\mathrm{Al}$ & 0.002 & & 0.010 & & - & & $0.010 J$ & & -5 & \\
\hline $\mathrm{Al}$ & 2.434 & & 2.128 & & 2.2607 & & 2.530 & & $2.248)$ & \\
\hline $\mathrm{Ti}$ & 0.001 & & 0.026 & & 0.009 & & 0.002 & & - & \\
\hline $\mathrm{Fe}^{3+}$ & 0.591 & 3.035 & 0.809 & 2.969 & 0.710 & 2.979 & 0.480 & 3.013 & 0.743 & 2.994 \\
\hline $\mathrm{Cr}$ & 0.009 & & 0.006 & & - & & 0.001 & & 0.003 & \\
\hline $\mathrm{Mg}$ & -7 & & - & & -7 & & - & & - & \\
\hline Mn & 0.008 & & 0.013 & & 0.005 & & 0.003 & & - & \\
\hline $\mathrm{Ca}$ & 1.941 & & 2.020 & & 1.994 & & 1.983 & & 1.994 & \\
\hline $\mathrm{Na}$ & - & 1.949 & 0.008 & 2.041 & - & 1.999 & - & 1.986 & - & 1.994 \\
\hline K & & & - & & - & & - & & - & \\
\hline Total & 7.984 & & 8.010 & & 7.992 & & 7.999 & & 7.996 & \\
\hline
\end{tabular}

Note: Site totals in right hand column for each analysis. Oxides given as wt. \%. Structural formulas calculated based on 12.5 oxygens, with $\mathrm{Fe}$ calculated as $\mathrm{Fe}^{+}+3$. Dashes indicate undetected elements, $\mathrm{n}$ $=$ not analyzed. $1=$ Epidote, in vein; Sample $89-2,58-62 \mathrm{~cm} .2,3=$ Euhedral epidote crystal in vein with quartz; Sample 90-1, 112-116 cm. 4, 5 = Euhedral epidote crystal in vein with scolecite; Sample 95-1, 34-36 cm.

$1328 \mathrm{~m}$ and is intergrown with talc replacing olivine from 1189 to $1328 \mathrm{~m}$. Occasionally red ferric oxide-hydroxide and/or pyrite are also associated with the magnetite.

Hematite has been observed in only three samples. It occurs as 3-6 $\mu \mathrm{m}$ platelets as overgrowths on titanomagnetite in centimeter-sized reddish alteration halos around a clay mineral vein in Sample 504B-76-1, 65-68 cm. Hematite occurs intergrown with quartz and rare pyrite in veins, appearing as fine-grained red material in hand specimen of Samples 504B-84-1, 23-26 cm; 504B-84-1, 54-60 $\mathrm{cm}$; and 504B-85-1, 49-53 cm.

\section{Prehnite}

Prehnite occurs throughout the hole below $897 \mathrm{~m}$ BSF. It occurs in minor amounts from 897 to $1039 \mathrm{~m}$ as 10 $50 \mu \mathrm{m}$ bundles or patches of brownish radiating fibers replacing quartz, laumontite, and heulandite in veins. Prehnite is more abundant below $1039 \mathrm{~m}$ and is most common below $1125 \mathrm{~m}$, especially at fine-grained dike margins. It occurs as colorless sheaves and euhedral prisms or brown spherules of radial fibers replacing laumontite, albite, and rarely anhydrite and scolecite in veins and vugs (Plate 1, Fig. 2; Plate 3, Fig. 4). Locally, prehnite partly replaces plagioclase and glass.

Microprobe analyses of prehnite are given in Table 8. Hole 504B prehnites generally contain low but variable amounts of iron. However, the lowermost samples (below $1322 \mathrm{~m}$ BSF) contain greater amounts of iron, up to
$4.84 \mathrm{wt} . \% \mathrm{FeO}$. No consistent difference in composition between brown fibrous and clear prismatic or sheaflike prehnite was observed.

\section{Quartz}

Quartz occurs mostly in veins as fine to coarse, euhedral to subhedral crystals. It generally follows clay mineral when associated, but is occasionally first in veins, sometimes replacing narrow $(100 \mu \mathrm{m})$ wall-rock zones. Quartz is commonly intergrown with epidote in veins and occasionally contains inclusions of actinolite needles and vermicular clay minerals (Plate 3, Figs. 1-3). It occurs in veins with sulfides in the mineralized stockwork zone (910-928 m) and locally partly replaces olivine phenocrysts along with clay minerals.

\section{Scolecite}

Scolecite occurs below $1030 \mathrm{~m}$ BSF as bundles of radiating fibers or acicular crystals, up to several $\mathrm{mm}$ long, most commonly in veins and vugs (Plate 1, Fig. 1). Scolecite is commonly associated with prehnite in veins and frequently partially replaces primary plagioclase in basalts containing scolecite veins.

Scolecite analyses and calculated formulas given in Table 9, are similar to those given in Deer et al., (1964), with very low $\mathrm{Na}_{2} \mathrm{O}$ contents and essentially no $\mathrm{K}_{2} \mathrm{O}$. However, an Na-rich scolecite (Table 9 Analysis 4) occurs with the Na-poor scolecite in a vein in Sample 504B-106-1, 
Table 5. Selected microprobe analyses of secondary feldspars, Hole 504B.

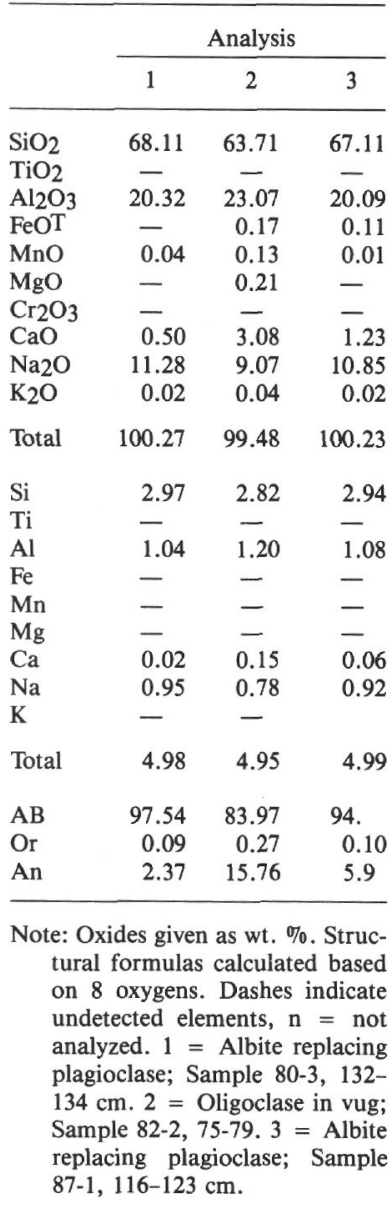

$86-88 \mathrm{~cm}$. Such a high $\mathrm{Na}_{2} \mathrm{O}$ content is unusual for scolecite, which usually has $\mathrm{Na}_{2} \mathrm{O}$ contents less than $0.7 \mathrm{wt} . \%$ (Foster, 1965).

\section{Sphene}

Sphene occurs throughout the hole in varying amounts below $836 \mathrm{~m}$ BSF as a replacement product of titanomagnetite and glass. It occurs most commonly as very fine-grained material along cracks in and surrounding titanomagnetite grains, or totally replacing titanomagnetite. Sphene also occurs as fine-grained brownish aggregates to clear euhedral crystals, up to $70 \mu \mathrm{m}$ in size, intergrown with chlorite and quartz in veins and associated recrystallized wall rock. Fine-grained sphene is commonly disseminated in chloritized glassy pillow rims. Microprobe analyses of sphene are given in Table 10. The frequently low totals, variable $\mathrm{TiO}_{2}$ contents (generally 30-37 wt.\%, but as low as 19 wt.\%), and high $\mathrm{Al}$ and $\mathrm{Fe}$ contents of the sphene analyses may be due in part to analytical difficulties: sphene grains are very small, and often consist of aggregates of microcrystalline material that may be intergrown with other phases (e.g., clay minerals).
Table 6. Selected microprobe analyses of heulandite, Hole 504B.

\begin{tabular}{lcccc}
\hline & \multicolumn{4}{c}{ Analysis } \\
\cline { 2 - 5 } & 1 & 2 & 3 & 4 \\
\hline $\mathrm{SiO}_{2}$ & 57.25 & 56.97 & 57.52 & 57.22 \\
$\mathrm{TiO}_{2}$ & 0.01 & - & - & - \\
$\mathrm{Al}_{2} \mathrm{O}_{3}$ & 18.36 & 17.67 & 19.07 & 17.44 \\
$\mathrm{FeO}(\mathrm{T})$ & 0.01 & - & - & - \\
$\mathrm{MnO}$ & - & - & - & 0.02 \\
$\mathrm{MgO}$ & 0.02 & .01 & - & - \\
$\mathrm{Cr} 2 \mathrm{O}_{3}$ & $\mathrm{n}$ & $\mathrm{n}$ & - & 0.06 \\
$\mathrm{CaO}$ & 7.47 & 9.12 & 8.62 & 9.10 \\
$\mathrm{Na} 2 \mathrm{O}$ & 0.95 & 0.13 & 0.26 & 0.49 \\
$\mathrm{~K} 2 \mathrm{O}$ & 2.08 & 0.53 & 0.06 & - \\
$\mathrm{Total}$ & 86.15 & 84.45 & 85.53 & 84.34 \\
$\mathrm{Si}$ & 26.20 & 26.36 & 26.16 & 26.48 \\
$\mathrm{Ti}$ & - & - & - & - \\
$\mathrm{Al}$ & 9.92 & 9.64 & 10.22 & 9.51 \\
$\mathrm{Fe}(\mathrm{T})$ & - & - & - & - \\
$\mathrm{Mn}$ & - & - & - & 0.01 \\
$\mathrm{Mg}$ & - & - & - & - \\
$\mathrm{Cr}$ & $\mathrm{n}$ & $\mathrm{n}$ & - & 0.02 \\
$\mathrm{Ca}$ & 3.68 & 4.52 & 4.20 & 4.51 \\
$\mathrm{Na}$ & 0.84 & 0.48 & 0.23 & 0.44 \\
$\mathrm{~K}$ & 1.20 & 0.08 & 0.03 & - \\
$\mathrm{Total}$ & 41.84 & 41.08 & 40.84 & 40.97 \\
\hline
\end{tabular}

Note: Oxides given as wt. \%. Structural formulas calculated based on 72 oxygens. Dashes indicate undetected elements, $\mathrm{n}=$ not analyzed. $1=\mathrm{K}$-rich heulandite replacing quartz in vein Sample $80-1$; $106-111 \mathrm{~cm} .2=\mathrm{Heu}-$ landite in vein; Sample 80-1, 106-111 cm. 3 = Heulandite replacing plagioclase phenocryst; Sample 82-2, 75-79 cm. $4=$ Heulandite in vein; Sample 89 $1,17-20 \mathrm{~cm}$.

\section{Stilbite}

Stilbite was identified by X-ray diffraction in a vein in Sample 504B-80-1, 30-32 cm, where it occurs with clay minerals, quartz, pyrite, sphalerite, chalcopyrite, calcite, and laumontite. Stilbite was not observed in thin section, however, so its relationship to the other minerals is unknown.

\section{Sulfides}

Sulfide minerals are briefly described here. A more detailed description including sulfur isotopic data is given by Honnorez et al. (this volume).

Pyrite is the most common sulfide, occurring throughout the Leg 83 section. It is frequently associated with clay minerals replacing olivine phenocrysts and is fairly common disseminated in the groundmass of the basalts. Veins containing pyrite and clay minerals and/or quartz occur throughout the Leg 83 section. Pyrite reaches maximum abundance in the stockwork zone, both disseminated in the rock and in veins. It decreases slightly in abundance from 928 to $967 \mathrm{~m}$ and is present in lesser amounts to the bottom of the transition zone.

Sphalerite is most common in veins in the stockworklike zone (910-928 m) as 0.1-1.6 mm crystals intergrown with pyrite, chalcopyrite, quartz, and occasionally chlo- 
Table 7. Selected microprobe analyses of laumontite, Hole 504B.

\begin{tabular}{lccccc}
\hline & \multicolumn{5}{c}{ Analysis } \\
\cline { 2 - 6 } & 1 & 2 & 3 & 4 & 5 \\
\hline $\mathrm{SiO}_{2}$ & 56.87 & 54.24 & 52.54 & 50.96 & 54.22 \\
$\mathrm{TiO}_{2}$ & 0.02 & 0.01 & - & - & - \\
$\mathrm{Al}_{2} \mathrm{O} 3$ & 22.53 & 21.83 & 21.19 & 22.27 & 21.59 \\
$\mathrm{FeO}(\mathrm{T})$ & - & - & - & - & 0.01 \\
$\mathrm{MnO}$ & - & - & 0.02 & - & - \\
$\mathrm{MgO}$ & - & - & 0.01 & - & - \\
$\mathrm{Cr} 2 \mathrm{O}_{3}$ & 0.02 & 0.02 & 0.08 & - & 0.01 \\
$\mathrm{CaO}$ & 8.84 & 11.05 & 11.27 & 12.13 & 10.98 \\
$\mathrm{Na} 2 \mathrm{O}$ & 3.24 & 0.61 & 0.26 & - & 0.30 \\
$\mathrm{~K} 2 \mathrm{O}$ & 0.05 & 0.16 & 0.04 & - & 0.06 \\
$\mathrm{Total}$ & 91.58 & 87.94 & 85.40 & 85.37 & 87.18 \\
$\mathrm{Si}$ & 16.4 & 16.32 & 16.29 & 15.85 & 16.39 \\
$\mathrm{Ti}$ & - & - & - & - & - \\
$\mathrm{Al}$ & 7.68 & 7.72 & 7.73 & 8.17 & 7.70 \\
$\mathrm{Fe}(\mathrm{T})$ & - & - & - & - & - \\
$\mathrm{Mn}$ & - & - & 0.01 & - & - \\
$\mathrm{Mg}$ & - & - & - & - & - \\
$\mathrm{Cr}$ & - & - & 0.02 & - & - \\
$\mathrm{Ca}$ & 2.72 & 3.56 & 3.74 & 4.04 & 3.56 \\
$\mathrm{Na}$ & 1.84 & 0.36 & 0.15 & - & 0.18 \\
$\mathrm{~K}$ & - & 0.08 & 0.02 & & 0.02 \\
$\mathrm{Total}$ & 28.68 & 28.04 & 27.96 & 28.06 & 27.85 \\
\hline & & & & &
\end{tabular}

Note: Oxides given as wt. \%. Structural formulas calculated based on 48 oxygens. Dashes indicate undetected elements, $\mathrm{n}=$ not analyzed. $1=\mathrm{Na}$ rich laumonite replacing analcite in vein; Sample 80-2, 91-97 cm. 2 = "Typical" laumonite replacing quartz in vein; Sample 80-2, 91-97 cm. $3=$ Laumonite in vein; Sample 90-1, 112-116 cm. 4 , 5 = Laumonite in vug; Sample 136-1, 24-29 cm. rite. Sphalerite often encloses $0.1-0.3 \mathrm{~mm}$ chalcopyrite grains. Chalcopyrite also occurs as small, micron-sized blebs or occasionally oriented laths in sphalerite as the result of both epitaxial growths and reaction with hydrothermal fluids to produce "chalcopyrite disease" (Honnorez et al., this volume).

Sphalerite crystals are zoned with alternating yellow and orange bands and with outer clear yellowish overgrowth, probably due to variations in iron content. Chalcopyrite replaces wall-rock fragments in a clay mineral vein and partly replaces adjacent wall rock in Sample 504B-94-1, 132-135 cm. Chalcopyrite and sphalerite occur together similarly in a vein of intergrown clay mineral (Type 4 mixture) and scolecite in Sample 504B-111-1, $41-45 \mathrm{~cm}$.

Minor amounts of galena were observed in several samples (Honnorez et al., this volume).

\section{Clay Minerals}

The various types of clay minerals described in the following sections generally have similar occurrences: they occur both filling cracks and in bulk rocks, where they fill primary void space and replace igneous minerals.

\section{Technique}

The clay minerals were identified by X-ray diffraction (XRD) of samples from bulk rocks, veins, and plucked from olivine pseudomorphs and vugs. Samples were from both Leg 83 and Leg 69 and 70 sections of the core. Oriented mounts were prepared by aspiration of clay sus-

Table 8. Selected microprobe analyses of prehnite, Hole 504B.

\begin{tabular}{|c|c|c|c|c|c|c|c|c|}
\hline & \multicolumn{8}{|c|}{ Analysis } \\
\hline & 1 & & 2 & & 3 & & 4 & \\
\hline $\mathrm{SiO}_{2}$ & 43.59 & & 43.80 & & 43.81 & & 43.45 & \\
\hline $\mathrm{TiO}_{2}$ & - & & - & & - & & 0.03 & \\
\hline $\mathrm{Al}_{2} \mathrm{O}_{3}$ & 21.79 & & 24.22 & & 24.40 & & 21.26 & \\
\hline $\mathrm{FeO}(\mathrm{T})$ & 2.25 & & 0.10 & & 0.63 & & 4.30 & \\
\hline $\mathrm{MnO}$ & 0.05 & & - & & 0.01 & & 0.01 & \\
\hline $\mathrm{MgO}$ & - & & - & & - & & - & \\
\hline $\mathrm{Cr}_{2} \mathrm{O}_{3}$ & - & & - & & 0.03 & & - & \\
\hline $\mathrm{CaO}$ & 26.27 & & 26.81 & & 26.43 & & 26.22 & \\
\hline $\mathrm{Na}_{2} \mathrm{O}$ & 0.08 & & 0.05 & & 0.02 & & 0.11 & \\
\hline $\mathrm{K}_{2} \mathrm{O}$ & 0.03 & & - & & 0.01 & & - & \\
\hline \multirow[t]{2}{*}{ Total } & 94.05 & & 94.99 & & 95.33 & & 95.39 & \\
\hline & 1 & & 2 & & 3 & & 4 & \\
\hline \multirow[t]{2}{*}{$\mathrm{Si}$} & 6.157 & & 6.05 & & $6.04)$ & & 6.11 & \\
\hline & -1 & -6.15 & & -6.05 & & -6.04 & & -6.1 \\
\hline Al & 3.62 & & 3.94 & & 3.96 & & 3.52 & \\
\hline $\mathrm{Ti}$ & - & & - & & - & & - & \\
\hline $\mathrm{Fe}(\mathrm{T})$ & 0.27 & & 0.01 & & 0.07 & & 0.51 & \\
\hline Mn & 0.02 & -3.90 & - & 3.95 & - & 4.03 & - & 4.03 \\
\hline $\mathrm{Mg}$ & - & & - & & - & & - & \\
\hline $\mathrm{Cr}$ & - & & - & & - & & - & \\
\hline $\mathrm{Na}$ & 0.02 & & 0.01 & & 0.01 & & 0.03 & \\
\hline $\mathrm{Ca}$ & 3.97 & -4.00 & 3.97 & -3.98 & 3.90 & 3.91 & 3.95 & 3.98 \\
\hline $\mathrm{K}$ & 0.01 & & - & & - & & - & \\
\hline
\end{tabular}

Note: Oxides given as wt. \%. Structural formulas calculated based on 24 oxygens (O, $\mathrm{OH})$. Dashes indicate undetected elements, $\mathrm{n}=$ not analyzed. $1=$ Brown spherules of prehnite replacing heulandite in vein; Sample 78-1, 8-11 cm. $2=$ Colorless prehnite prism in vein; Sample $99-1,137-140 \mathrm{~cm} .3=$ Colorless prehnite adjacent to brown spherule in vein; Sample 116-1, 128-130. $4=$ Colorless prehnite spherule in vein; Sample 139-1, 37-41 cm. 
Table 9. Selected microprobe analyses of scolecite, Hole 504B.

\begin{tabular}{lcccc}
\hline & \multicolumn{4}{c}{ Analysis } \\
\cline { 2 - 5 } & 1 & 2 & 3 & 4 \\
\hline $\mathrm{SiO}_{2}$ & 44.46 & 45.16 & 44.75 & 48.66 \\
$\mathrm{TiO}_{2}$ & - & - & - & - \\
$\mathrm{Al}_{2} \mathrm{O}_{3}$ & 25.42 & 26.35 & 25.92 & 24.06 \\
$\mathrm{FeO}(\mathrm{T})$ & - & 0.25 & - & - \\
$\mathrm{MnO}$ & - & - & 0.06 & 0.03 \\
$\mathrm{MgO}$ & - & 0.01 & - & - \\
$\mathrm{Cr} 2 \mathrm{O}_{3}$ & - & 0.07 & - & - \\
$\mathrm{CaO}$ & 13.51 & 12.87 & 13.74 & 9.35 \\
$\mathrm{Na} 2 \mathrm{O}$ & 0.19 & 0.47 & 0.29 & 2.20 \\
$\mathrm{~K} 2 \mathrm{O}$ & - & 0.01 & - & - \\
$\mathrm{Total}$ & 83.58 & 85.19 & 84.77 & 84.31 \\
$\mathrm{Si}$ & 23.95 & 23.85 & 23.80 & 25.60 \\
$\mathrm{Ti}$ & - & - & - & - \\
$\mathrm{Al}$ & 16.13 & 16.40 & 16.25 & 14.92 \\
$\mathrm{Fe}(\mathrm{T})$ & - & 0.11 & - & - \\
$\mathrm{Mn}$ & - & - & 0.03 & 0.01 \\
$\mathrm{Mg}$ & - & 0.01 & - & - \\
$\mathrm{Cr}$ & - & 0.03 & - & - \\
$\mathrm{Ca}$ & 7.80 & 7.28 & 7.83 & 5.27 \\
$\mathrm{Na}$ & 0.20 & 0.48 & 0.30 & 2.25 \\
$\mathrm{~K}$ & & - & - & - \\
$\mathrm{Total}$ & 48.08 & 48.16 & 48.21 & 48.05 \\
\hline
\end{tabular}

Note: Oxides given as wt. \%. Structural formulas calculated based on 80 oxygens. Dashes indicate undetected elements, $\mathrm{n}=$ not analyzed. 1 = Scolecite in vein; Sample 94-3, 67-72 cm. $2=$ Scolecite replacing plagioclase phenocryst; Sample 103-1, 31-34 cm. $3=$ Scolecite in vein; Sample 106-1, 86-88 $\mathrm{cm} .4$ = Na-rich scolecite in same vein as Analysis 3; Sample 106-1, 86-88 cm.

pensions onto $0.45-\mu \mathrm{m}$ silver filters and were scanned with the diffractometer from 15 to $2^{\circ} 2 \theta$ at $1^{\circ} / \mathrm{min}$. ( $\mathrm{CuK} \alpha$ radiation). Oriented mounts were scanned after air drying, treatment with ethylene glycol (E.G.), and heating to $300^{\circ} \mathrm{C}$ for two hours. Heat treatments at 400 $500^{\circ} \mathrm{C}$ generally resulted in total destruction of the clay minerals, while heating to $200^{\circ} \mathrm{C}$ did not cause collapse of most samples. Over 100 samples were studied using the previous techniques. In addition, about half of the samples were saturated with magnesium and treated with glycerol to distinguish between smectite and vermiculite (smectite expands after this treatment, whereas vermiculite does not; Brindley and Brown, 1980). Random mounts of several representative samples of each type of clay mineral were also prepared either as powder mounts or smear slides to determine structural type.

\section{Chlorite}

Pure chlorite was identified in only 32 samples (Table 11). Chlorite is indicated by the presence of 14 and $7 \AA$ peaks that do not expand after E.G. treatment and contract only slightly upon heating (the $14 \AA$ peak may shift to about $13.8 \AA$ ). XRD patterns from random mounts indicate that the chlorites are of the IIB structural type (Brindley and Brown, 1980). All samples exhibit 060 peaks from 1.540 to $1.550 \AA$ indicating trioctahedral structures.

Chlorite is occasionally a pale brownish color, but is generally pleochroic green to tan or colorless. It gener-
Table 10. Microprobe analyses of sphene, Hole 504B.

\begin{tabular}{lcc}
\hline & \multicolumn{2}{c}{ Analysis } \\
\cline { 2 - 3 } & 1 & 2 \\
\hline $\mathrm{SiO}_{2}$ & 29.39 & 30.59 \\
$\mathrm{TiO}_{2}$ & 28.78 & 30.95 \\
$\mathrm{Al}_{2} \mathrm{O}_{3}$ & 3.19 & 4.28 \\
$\mathrm{FeO}(\mathrm{T})$ & 2.16 & 2.18 \\
$\mathrm{MnO}$ & 0.08 & 0.08 \\
$\mathrm{MgO}$ & 0.15 & 0.27 \\
$\mathrm{Cr} 2 \mathrm{O}_{3}$ & $\mathrm{n}$ & $\mathrm{n}$ \\
$\mathrm{CaO}$ & 28.45 & 27.39 \\
$\mathrm{Na} 2 \mathrm{O}$ & 0.08 & 0.05 \\
$\mathrm{~K} 2 \mathrm{O}$ & 0.01 & - \\
$\mathrm{Total}$ & 92.29 & 95.79 \\
$\mathrm{Si}$ & 4.03 & 4.05 \\
$\mathrm{Ti}$ & 2,97 & 3.08 \\
$\mathrm{Al}$ & 0.52 & 0.67 \\
$\mathrm{Fe}$ & 0.25 & 0.24 \\
$\mathrm{Mn}$ & - & - \\
$\mathrm{Mg}$ & 0.03 & 0.05 \\
$\mathrm{Ca}$ & 4.18 & 3.89 \\
$\mathrm{Na}$ & 0.02 & 0.01 \\
$\mathrm{~K}$ & - & - \\
$\mathrm{Total}$ & 12.00 & 11.99 \\
\hline
\end{tabular}

Note: Oxides given as wt. $\%$. Structural formulas based on 20 oxygens. Dashes indicate undetected elements, $\mathrm{n}=$ not analyzed. $=$ Brownish sphene in clay mineral vein adjacent to extensively altered wall rock; Sample $81-1,83-86$ $\mathrm{cm} .2$ = Clear subhedral sphene crystals in clay minera vein adjacent to wal rock; Sample 87-1, $116-123 \mathrm{~cm}$.

ally exhibits anomalous blue interference colors, but occasionally exhibits lower first-order colors.

\section{Chlorite-Expandable Clay Mixtures}

Most of the sheet silicates in Leg 83 samples are mixtures of variable amounts of chlorite and expandable clay minerals (smectite and vermiculite), ranging from nearly pure chlorite to nearly pure expandable clays. Chlorite, smectite and vermiculite all have 001 and 002 peaks at about 14 and $7 \AA$, respectively. However, the chlorite 002 peak intensity is greater than the 001 intensity, while in smectite and vermiculite the relative intensities are reversed. Also, $00 \ell \mathrm{d}$-spacings of the expandable clays increase after E.G. treatment and collapse after heating, whereas chlorite peaks remain essentially unchanged by these treatments. Chlorite-expandable clay mixtures were divided into five categories based on the behavior and relative intensities of $00 \ell$ peaks after air drying and E.G. treatment (Fig. 3; Table 11).

1. Chlorite with minor expandable layers: After E.G. treatment chlorite 001 and 002 peaks become asymmetric toward low angles (higher d-spacing) because of the presence of minor expandable layers. The 002 peak in- 
Table 11. Clay mineral X-ray diffraction results, Hole 504B.

\begin{tabular}{|c|c|c|c|}
\hline Sample (interval in $\mathrm{cm}$ ) & Vein & $\begin{array}{l}\text { Alteration halo } \\
\text { (if present) }\end{array}$ & Host rock \\
\hline $72-2,126-129$ & & 5 & 5 \\
\hline $72-3,142-144$ & 5 & & \\
\hline $73-2,29-32$ & 5 & & 5 \\
\hline $74-1,5-8$ & 5 & & 5 (glass $=5$ ) \\
\hline $74-1,46-49$ & 4 & & RML \\
\hline $75-1,1-4$ & 5 & & $5(\mathrm{~T})$ \\
\hline $76-1,65-68$ & 4 & & 5 \\
\hline $77-2,71-73$ & $\mathrm{C}$ & & \\
\hline $78-1,102-106$ & 2 & & 3 \\
\hline $79-2,62-66$ & 1 & RML & RML \\
\hline $79-3,147-149$ & & & RML \\
\hline $80-1,34-38$ & & & 1 \\
\hline $80-1,106-111$ & 1 & & 1 \\
\hline $80-2,63-67$ & 1 & & 2(Act) \\
\hline $80-3,107-110$ & 2 & & \\
\hline $80-3,113-119$ & 2 & & 1 \\
\hline $81-1,76-79$ & 2 & & 4 \\
\hline $81-1,83-86$ & 1 & & 1 (glass $=C$ ) \\
\hline $82-1,46-49$ & 2 & & \\
\hline $82-1,68-73$ & 1 & 2 & 2 \\
\hline $82-1,90-96$ & & & glass-1 \\
\hline $83-1,29-33$ & $\mathrm{C}$ & & \\
\hline $84-2,48-50$ & & & 2 \\
\hline $87-1,116-123$ & $\mathrm{C}$ & $\mathrm{C}$ & 1 \\
\hline $89-1,17-20$ & $\mathrm{C}$ & & \\
\hline $91-1,66-70$ & & 4 & 4 \\
\hline $94-1,9-12$ & & & 4 \\
\hline $94-1,132-135$ & $\mathrm{C}$ & & 1 (T,Act) \\
\hline $94-3,10-18$ & C & & \\
\hline $95-1,54-59$ & $\mathrm{C}$ & & \\
\hline $95-1,75-77$ & 2 & & \\
\hline $95-1,140-143$ & & & $C($ Act $)$ \\
\hline $97-1,82-84$ & & & 1 \\
\hline $97-1,88-90$ & & & 1 \\
\hline $97-2,22-25$ & & & $4(T)$ \\
\hline $99-1,70-74$ & $\mathrm{C}$ & & $C($ Act $)$ \\
\hline $99-1,137-140$ & $\mathrm{C}$ & & \\
\hline $99-2,42-50$ & $\mathrm{C}$ & & $\mathrm{C}$ \\
\hline $100-1,83-87$ & $C($ Act $)$ & & \\
\hline $101-1,46-48$ & C & & \\
\hline $101-1,134-138$ & $\mathrm{C}$ & & \\
\hline $102-1,24-30$ & & 1 & \\
\hline $103-1,31-34$ & & & $\mathrm{C}$ \\
\hline $104-2,48-55$ & 2 & 2 & \\
\hline $104-2,57-65$ & & $\mathrm{C}$ & 4 \\
\hline $104-2,67-72$ & & & 3 \\
\hline $104-2,75-82$ & & & 4 \\
\hline $105-1,26-28$ & $\mathrm{C}$ & & \\
\hline $106-1,82-85$ & 2 & & \\
\hline $107-1,90-92$ & RML & & 4 \\
\hline $109-1,28-31$ & & & 2(Act) \\
\hline $111-1,41-45$ & 4 & & 4 \\
\hline $111-1,71-73$ & RML & & RML \\
\hline $113-1,47-50$ & & & $2(\mathrm{~T}, \mathrm{Act})$ \\
\hline $116-1,128-130$ & $\mathrm{C}$ & & \\
\hline $117-1,100-101$ & & & $3(\mathrm{~T})$ \\
\hline $117-1,109-113$ & & & RML \\
\hline $121-1,65-69$ & & & 2 \\
\hline $122-1,4-27$ & 1 & & \\
\hline $123-2,58-62$ & & & $\mathrm{C}(\mathrm{T}, \mathrm{Act})$ \\
\hline $127-1,109-112$ & & & 5 \\
\hline $129-1,33-35$ & & & 3 (T,Act) \\
\hline $129-2,23-27$ & 4 & & $4(\mathrm{~T})$ \\
\hline $130-2,43-44$ & & & 2 (T, Act) \\
\hline $132-1,118-122$ & & & 2 (Act) \\
\hline $133-2,34-43$ & & 2 (Act) & C (Act) \\
\hline $134-1,147-150$ & & $\mathrm{C}(\mathrm{T}, \mathrm{Act})$ & C (Act) \\
\hline $139-1,23-26$ & C & & \\
\hline $139-1,29-33$ & & & 1 (Act) \\
\hline $139-1,37-46$ & 1 & & C (Act) \\
\hline $141-1,64-66$ & C & & \\
\hline $141-1,67-71$ & & & $\mathrm{C}$ (Act) \\
\hline $141-1,71-74$ & $\mathrm{C}$ & & 2 \\
\hline $141-1,74-78$ & C & & \\
\hline
\end{tabular}

Note: $\mathrm{C}=$ chlorite; $1-5=$ chlorite-expandable clay mixtures (see text); RML = regular mixed-layer chlorite-smectite; $\mathrm{T}=$ talc; Act $=$ actinolite; glass $=$ means replacement product of basaltic glass at pillow rim, parentheses indicate minor or associated phases. tensity is always greater than that of the 001 , as in pure chlorite. Type 1 mixtures are optically indistinguishable from chlorite.

2. Chlorite > expandable clay: In these samples the 002 peak intensity is greater than that of the 001 , but the 001 peak either expands slightly (up to $14.7 \AA$ ) or breaks up into expanded (16.3-17.0 $)$ and nonexpanded $(\sim 14 \AA)$ peaks after E.G. treatment. Type 2 mixtures are pleochroic green to tan or colorless and exhibit lower first-order interference colors and rarely anomalous blue colors.

3. Chlorite = expandable clay: These samples exhibit similar behavior to the Type 2 samples after E.G.treatment, but the 001 peak generally expands more (to $15-$ $16.5 \AA$ ) and the 002 peak also expands slightly. The 001 and 002 peak intensities are nearly identical. Type $3 \mathrm{mix}-$ tures are pleochroic green to slightly brownish and exhibit lower first-to middle second-order interference colors.

4. Expandable clay $>$ chlorite: In these samples the 001 peak intensity is greater than that of the 002 peak, as in pure smectite and vermiculite. Greater expansion and separation of the expanded and nonexpanded peaks also occurs; the 001 peak generally expands closer to 16 $\AA$, while the 002 peak expands more than in Type 3 mixtures, with a distinct chlorite 002 peak visible. Type 4 mixtures are pleochroic olive green to brown and exhibit middle first- to upper second-order interference colors.

5. Expandable clay with minor chlorite: These samples behave nearly as pure expandable clays: the 001 peak intensity is much greater than the 002. After E.G. treatment the 001 and 002 peaks expand to greater than $16 \AA$ and about $8.3 \AA$, respectively. The only difference from pure smectite and vermiculite is that a small chlorite 002 peak is visible at about $7 \AA$ after E.G. treatment. Type 5 mixtures are optically indistinguishable from Type 4 mixtures.

Pure vermiculites should expand to 15.5 to $16.6 \AA$ and smectites to 16.4 to $17.1 \AA$ after E.G. treatment (Brindley and Brown, 1980). The smaller $001 \mathrm{~d}$-spacings (as low as $14.2 \AA$ ) of some of the E.G.-treated Type 2 mixtures may be due to random mixed layering, which would result in the presence of a peak somewhere between the chlorite (14 A) and expanded vermiculite and smectite (15.5-17.1 A) peaks.

The expandable clay mineral components of these five mixtures consist of variable combinations of smectite and vermiculite. These expandable components were classified into different categories, similar to these for the chlorite-expandable clay mixtures, based on the behavior and relative intensities of expanded and nonexpanded 001 peaks after air drying, saturation with magnesium, and glycerol treatments (Figs. 1 and 3). The categories of expandable components determined are (a) Smectite: A distinct expandable smectite 001 peak occurs at 16.3$18.0 \AA$ after $\mathrm{Mg}$-saturation and glycerol treatments, with no evidence of a nonexpanded vermiculite 001 peak. (b) Smectite > vermiculite: A distinct expanded smectite 001 peak occurs at $15.5-18.0 \AA$, and either a smaller nonexpanded vermiculite 001 peak occurs at $\sim 14.3 \AA$ after $\mathrm{Mg}$-saturation and glycerol treatments or the expanded smectite 001 peak is asymmetric toward higher 

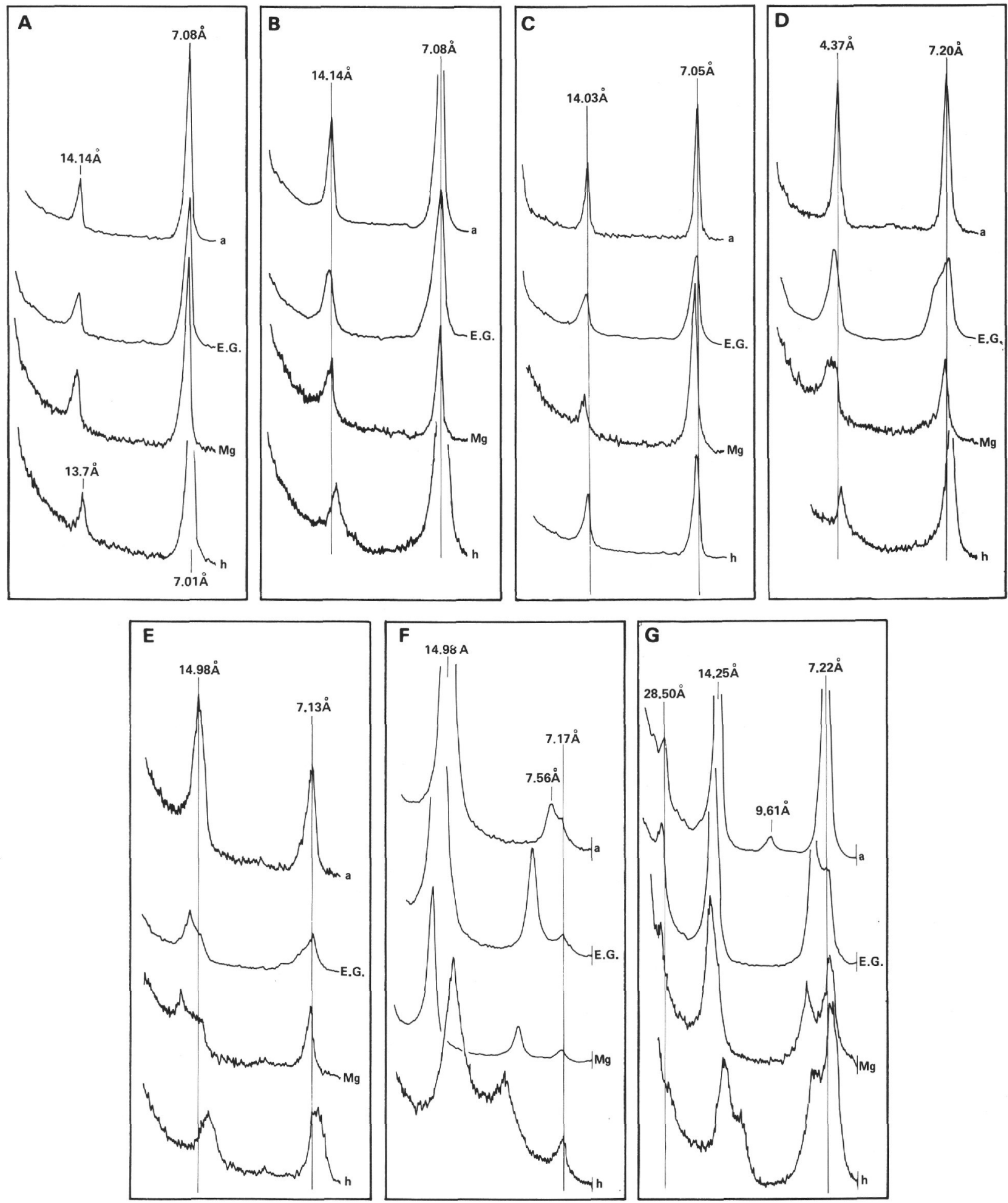

Figure 3. Partial X-ray diffractograms of clay minerals from Leg 83 basalts. See text for explanation of classification. a = air dried, E.G. $=$ treated with ethylene glycol, $\mathrm{h}=$ heated at $300^{\circ} \mathrm{C}$ for 2 hours, $\mathrm{Mg}=\mathrm{Mg}$-saturated and treated with glycerol. A. Chlorite replacing olivine in light gray alteration halo, Sample 504B-87-1, 116-123 cm. B. Type 1 mixture (chlorite with minor expandable layers) replacing olivine in dark gray host rock adjacent to A. Expandable component classified as vermiculite < smectite (Type d in text). Sample 504B-87-1, 116-123 cm. C. Type 2 mixture (chlorite > expandable clay) replacing olivine in light gray alteration halo. Expandable component is Type d (vermiculite < smectite). Sample 504B-104-2, 48-55 cm. D. Type 3 mixture (chlorite = expandable clay) replacing olivine in dark gray host rock adjacent to C. Expandable component is Type c (smectite = vermiculite). Sample 504B-104-2, 67-71 $\mathrm{cm}$. E. Type 4 mixture (expandable clay < chlorite) replacing olivine in dark gray basalt. Expandable component is Type b (smectite > vermiculite). Sample 504B-107-1, 90-92 cm. F. Type 5 mixture (expandable clay with minor chlorite layers) in vein of dark gray host rock. Expandable component is Type a (pure smectite). Sample 504B-73-2, 29-32 cm. G. Regular-mixed-layer chlorite-smectite replacing olivine in light gray alteration halo. Sample 504B-79-2, 62-66 cm. 
angles (lower d-spacings). (c) Smectite = vermiculite: $\mathbf{A}$ broad 001 peak consisting of expanded smectite and nonexpanded vermiculite components occurs from 14.5 to $16.5 \AA$ after $\mathrm{Mg}$-saturation and glycerol treatments. (d) Vermiculite < smectite: After Mg-saturation and glycerol treatments either a single nonexpanded vermiculite 001 peak occurs at 14.3-14.5 $\AA$ and is asymmetric toward lower angles (higher d-spacing) or two peaks occur-a nonexpanded vermiculite 001 peak at $\sim 14.4 \AA$, and a smaller expanded smectite 001 peak at 15.3-17.7 $\AA$. (e) Vermiculite: No expansion of the $\sim 14$ A peak occurs after $\mathrm{Mg}$-saturation and glycerol treatments.

Because of the variability of the chlorite 001-002 peak intensity ratios and the coincidence of the chlorite and vermiculite 001 peaks at about $14 \AA$, it was sometimes difficult to determine whether vermiculite was present for samples with small amounts of expandable layers. These samples are plotted as bars connecting points in Columns $a$ and $b$ in Figure 1 to show this uncertainty.

Behavior of $00 \ell$ peaks of Leg 83 samples after heat treatments suggests that they are mixtures of chlorite with smectite and vermiculite rather than swelling chlorite (Stephen and MacEwan, 1950; Martin-Vivaldi and MacEwan, 1960). In all of the clay mineral mixtures the 001 and 002 peak intensities decrease after heating. The 001 peaks decrease more than the 002 peaks, especially in expandable clay samples, and collapsed smectite-vermiculite 001 peaks (at 9-12 A) are only rarely visible, suggesting that the expandable layers are preferentially destroyed by heating. Swelling chlorite peak intensities should not decrease after heating, and in fact the 001 peak may increase in intensity (Stephen and MacEwan, 1950; Brindley and Brown, 1980), suggesting that swelling chlorite is not present in Leg 83 samples. The chlorite in all of the mixtures is of the IIB structural type, as determined from random mounts. All mixtures are trioctahedral, with 060 peaks at $1.54-1.55 \AA$.

\section{Regular-Mixed-Layer Chlorite-Smectite}

Regular-mixed-layer (RML) chlorite-smectite has been identified in seven samples (Figs. 1 and 3). Regular interstratification is indicated by the presence of a superlattice peak at $28.5 \AA$ with integral higher order $00 \ell$ reflections. Expansion of the basal peak to $30.5 \AA$ after E.G. treatment suggests regular interlayering of chlorite $(14 \AA)$ and an expandable $14 \AA$ mineral. Expansion of the $00 \ell$ spacings after $\mathrm{Mg}$-saturation and glycerol treatment indicates the presence of smectite as the expandable component. The decrease on intensity of the $14 \AA$ peak after heat treatment suggests the presence of smectite rather than swelling chlorite, which should exhibit increased 14 A peak intensity (Stephen and MacEwan, 1950; Brindley and Brown, 1980). The RML clay minerals found in Hole 504B are thus not corrensite, which consists of regularly interstratified chlorite and swelling chlorite (Martin-Vivaldi and MacEwan, 1960).

Unmixed chlorite, smectite, and vermiculite layers are also present. The small size of the RML 001 peak in most samples indicates less than perfect 1:1 ordering (April, 1980). Unmixed chlorite in all but one sample is indicated by the presence of 7.06-7.20 $\AA$ chlorite 002 peaks after E.G. treatment, which are distinct from the RML 004 peaks at about $7.6 \AA$. The presence of a $16.3 \AA$ smectite 001 peak after E.G. treatment, distinct from the expanded RML 002 peak at about $15 \AA$, indicates the presence of unmixed smectite in another sample. Sample 504B-111-1, 71-73 cm exhibits only integral RML 00 peaks and consists essentially of a 1:1 interstratification of chlorite and smectite. After E.G. treatment the RML 002 peak intensity of this sample is less than that of the RML 001 peak, as is the case for a similar 1:1 RML chlorite-vermiculite described by April (1980). The relative peak intensities of the other RML samples from Hole 504B are the reverse, however, suggesting a contribution from unmixed smectite layers to the RML 002 peak intensity of these samples.

The RML clay minerals are pleochroic green to tan and exhibit middle first- to middle second-order interference colors. They are indistinguishable in thin section from the other chlorite-expandable clay mixtures in the hole.

\section{Composition of Chlorite and Chlorite-Expandable Clay Mixtures}

Composition and optical properties of chlorite-expandable clay minerals from Leg 83 basalts are generally not sufficient to distinguish their structural type as determined by X-ray diffraction. However, samples rich in expandable layers (Type 4 and 5 mixtures) can generally be distinguished from chlorite-rich samples (chlorite and Type 1-3 mixtures), both optically and by composition, although a continuous gradation occurs between the endmember structural types.

Chlorite and Type 1-3 mixtures are generally pleochroic green to tan or colorless and exhibit anomalous blue to middle second-order interference colors. Type 4 and 5 mixtures are generally pleochroic olive green or yellow to brown and exhibit middle first- to upper second-order interference colors.

Chlorites and chlorite-expandable clay mixtures fall mostly within the pycnochlorite field of Hey's (1954) chlorite classification diagram (Fig. 4) and exhibit a trend of decreasing $\mathrm{Fe}$ with increasing $\mathrm{Si}$ and $\mathrm{Mg}$. Chlorite and Type 1-3 mixtures plot almost exclusively within the pycnochlorite field, with expandable clay-bearing mixtures extending to lower $\mathrm{Fe}^{\mathrm{T}} /\left(\mathrm{Fe}^{\mathrm{T}}+\mathrm{Mg}\right)$ values than the chlorites. In contrast, Type 4 and 5 mixtures and smectite plot in the lower right corner of the pycnochlorite field and extend through the diabantite and talc-chlorite fields to lower $\mathrm{Fe}^{\mathrm{T}} /\left(\mathrm{Fe}^{\mathrm{T}}+\mathrm{Mg}\right)$ values and much higher $\mathrm{Si}$ values.

Compositions of chlorite and chlorite-expandable clay mixtures from Hole 504B overlap other reported analyses of chlorites from various types of submarine metabasalts (Fig. 5). Figure 5 also shows the change in composition with clay mineral structural type. Although there is a large overlap, the fields of chlorite-expandable clay mixtures extend to higher $\mathrm{MgO} / \mathrm{FeO}$ ratios than the pure chlorites, with Type 4 and 5 mixtures also extending to higher $\mathrm{MgO} / \mathrm{Al}_{2} \mathrm{O}_{3}$ ratios.

Compositional heterogeneity of clay minerals is generally very slight within a single alteration zone (with the 


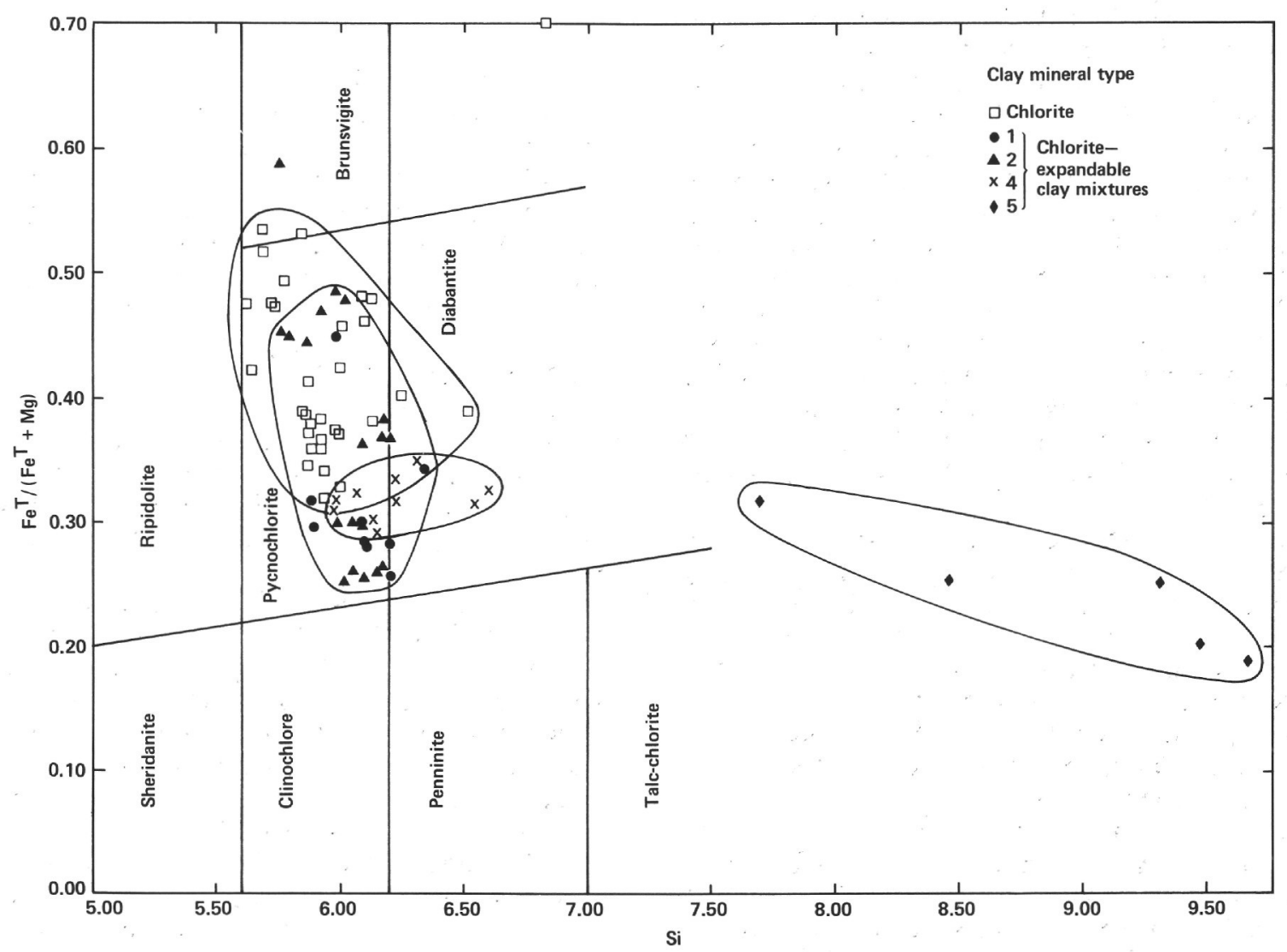

Figure 4. Leg 83 clay minerals identified by X-ray diffraction and analyzed by electron microprobe plotted on a chlorite classification diagram (after Hey, 1954). Formulas calculated on the basis of 56 oxygens. Fields of chlorite, Types 1, 2, 4, and 5 indicated on diagram. See text and Figure 3 for explanation of clay mineral types.

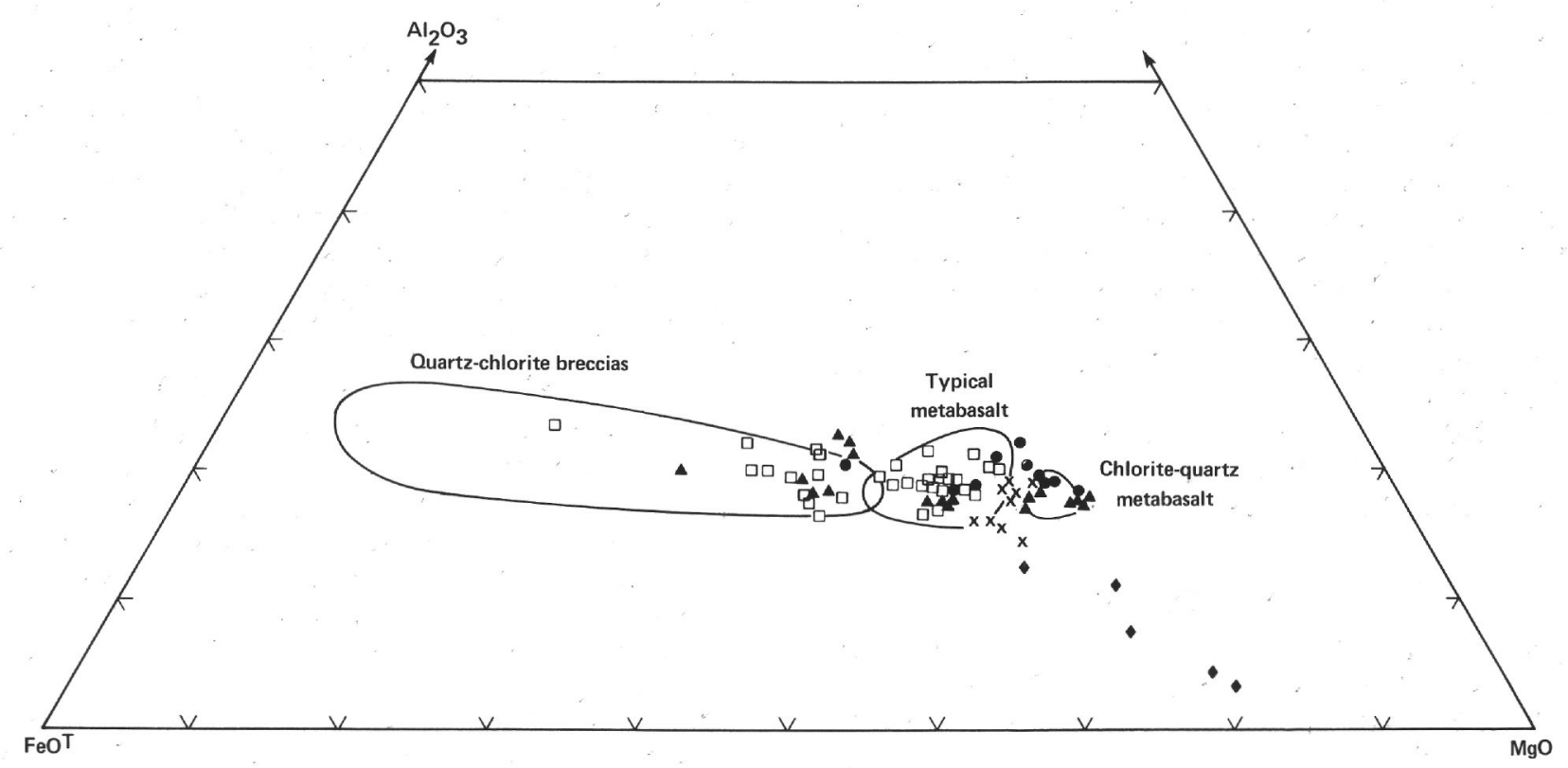

Figure 5. AFM diagram (components expressed as mole percent) showing compositions of clay minerals from Leg 83 basalts. Clay mineral types were determined by X-ray diffraction (see text and Fig. 3). Fields of chlorite-quartz breccias, "typical metabasalts," and chloritequartz-rich metabasalts from data in Mottl (1983). Symbols as in Figure 4. 
exception of the zoned talc/chlorite-expandable clay replacements of olivine). However, some significant variations in composition occasionally do occur. In Sample 504B-104-2, 75-82 cm, compositionally more chloritic clay minerals (lower $\mathrm{Si}$ and $\mathrm{Mg}$, higher $\mathrm{Al}$ and $\mathrm{Fe}$ ) were observed as discrete small patches within more smectitic clays replacing olivine, and botryoids of fibrous clay minerals in veins occasionally exhibit covarying $\mathrm{Si}-\mathrm{Al}$ and Mg-Fe (Samples 504B-73-2, 29-32 cm and 504B-80-1, $106-111 \mathrm{~cm}$ ). Variations in $\mathrm{Fe}$ and $\mathrm{Mg}$ occur in Samples 504B-139-1, 23-26 cm and 504B-141-1, 71-74 cm, with one analysis from each plotting at the highest $\mathrm{Fe}$ concentrations in Figure 4. Such heterogeneity could affect X-ray diffraction classification of clay mineral separates and is probably responsible for some of the overlap of the various structural types on compositional diagrams (Figs. 4 and 5).

Clay minerals exhibit significant compositional and structural trends with depth in the hole (Fig. 6). Clay minerals are enriched in Mn from 910 to 960 m BSF, with a maximum around $910-928 \mathrm{~m}$, coinciding with the sulfide-rich stockwork-like zone. Chlorite-rich clay minerals (chlorite and Type 1 and 2 mixtures) are also enriched in $\mathrm{Mg}$ and depleted in $\mathrm{Fe}$ in the stockwork-like zone. Iron exhibits maximums around 1040-1070 m and in the lowermost $15 \mathrm{~m}$ of the core.

Clay minerals become more chlorite-rich and the expandable component becomes more vermiculitic from about 825 to $900 \mathrm{~m}$, at the top of the transition zone (846 m; Fig. 1). The expandable component then becomes slightly less vermiculite-rich below about $1050 \mathrm{~m}$, near the bottom of the transition zone $(1055 \mathrm{~m})$.

\section{Talc}

Talc occurs locally replacing olivine (Fig. 1) and is always associated with chlorite-expandable clay mixtures. Talc is visible in thin section (colorless, third-order red interference colors) intergrown with magnetite replacing olivine in dikes from 1189 to $1319 \mathrm{~m}$ BSF (Plate 6, Fig. 3 ), but only colored clay minerals are observed in other samples where talc was identified by X-ray diffraction, along with chlorite-expandable clay mixtures (Samples 504B-72-2, 126-129 cm; 504B-75-1, 75-79 cm; 504B-91-1, 66-70 cm; 504B-113-1, 47-50 cm). When calculated on the basis of 22 oxygens (Table 12, Analyses 14, 16), the formulas of colorless talc are only slightly different from that of ideal saponite. Talc in Leg 83 samples is slightly richer in Fe than talc occurring in a vein in pillow basalts recovered from the hole during Leg 70 (Laverne, 1983).

\section{ALTERATION DESCRIPTION}

Based on the distribution of secondary minerals with depth in the Leg 83 section (Fig. 1), the section can be divided into two different zones: (1) pillows and upper transition zone from 836 to $898 \mathrm{~m}$, and (2) transition zone and dike sections from $898 \mathrm{~m}$ to the bottom of the hole $(1350 \mathrm{~m})$. Alteration of the basalts is described according to this division.

\section{Pillows and Upper Transition Zone (836-898 m)}

The $10 \mathrm{~m}$ of pillows and the upper most $42 \mathrm{~m}$ of the transition zone (Cores 504B-71-77) exhibit similar alteration effects: the rocks are uniformly dark gray, appearing only slightly altered in hand specimen (Plate 4, Fig. 2).

Olivine is completely replaced and voids are filled with clay minerals, almost all of which have very large expandable components (Table 11; Fig. 1). Pyrite occurs as 10-300 $\mu \mathrm{m}$ grains associated with clay minerals replacing olivine. Quartz is also present with clay minerals replacing olivine and filling voids in Sample 504B-74-1, $46-49 \mathrm{~cm}$. Plagioclase is unaltered to only partly replaced by clay minerals, especially along cracks; clinopyroxene is mostly unaltered; titanomagnetite is partly to extensively replaced by sphene. Pyrite is commonly disseminated in the groundmass, occasionally oriented in "stringers" parallel to and a few millimeters from clay mineral veins.

In several samples plagioclase and clinopyroxene in the wall rock within $1 \mathrm{~mm}$ of veins are extensively altered to clay minerals and titanomagnetite is replaced by sphene. Glassy pillow rims are also totally replaced by clay minerals and sphene. In Sample 504B-76-1, 65-68 cm hematite occurs as 3-6 $\mu \mathrm{m}$ platelets as overgrowths on primary titanomagnetite and with secondary magnetite, pyrite, and clay minerals replacing olivine.

Veins consist of clay minerals (Table 11) and small amounts of pyrite, commonly with calcite and anhydrite at the center, and rarely with quartz bounding the walls.

\section{Transition Zone and Sheeted Dikes (898-1350 m)}

Greenchist facies minerals first appear at $898 \mathrm{~m} \mathrm{BSF}$ (in Core 504B-78) in the transition zone and are present in varying amounts to the bottom of the hole $(1350 \mathrm{~m}$, Core 504B-141), distinguishing alteration of these rocks from that of the overlying basalts (Fig. 1). Fine-grained pillows and dike margins are generally a light greenish gray color, but may be an even lighter gray for up to a few centimeters around veins and at pillow rims and brecciated dike margins (Plates 4 and 5). Coarse-grained massive flows and dikes are generally a dark greenish gray color, with up to $3 \mathrm{~cm}$ (usually $\leq 1 \mathrm{~cm}$ ) lighter greenish gray alteration zones around cracks (Plate 5).

\section{Primary Mineral Alteration}

Olivine is completely altered to clay minerals. Pyrite is often associated with clay minerals replacing olivine as 10-300 $\mu$ m grains (Plate 6, Fig. 1). From 914 to $955 \mathrm{~m}$ and in samples from 968 and $998 \mathrm{~m}$, quartz often occurs as $50-\mu \mathrm{m}$ anhedral grains forming rims around the inside of clay mineral pseudomorphs of olivine phenocrysts and (rarely) partly filling the interiors of the pseudomorphs (Plate 6, Fig. 2).

Common secondary magnetite and rare ferric oxide/ hydroxides are intergrown with clay minerals replacing olivine from 1117 to $1139 \mathrm{~m}$. Talc and magnetite, with minor pyrite, frequently replace the outer rims of olivine phenocrysts, whereas other clay minerals (generally 


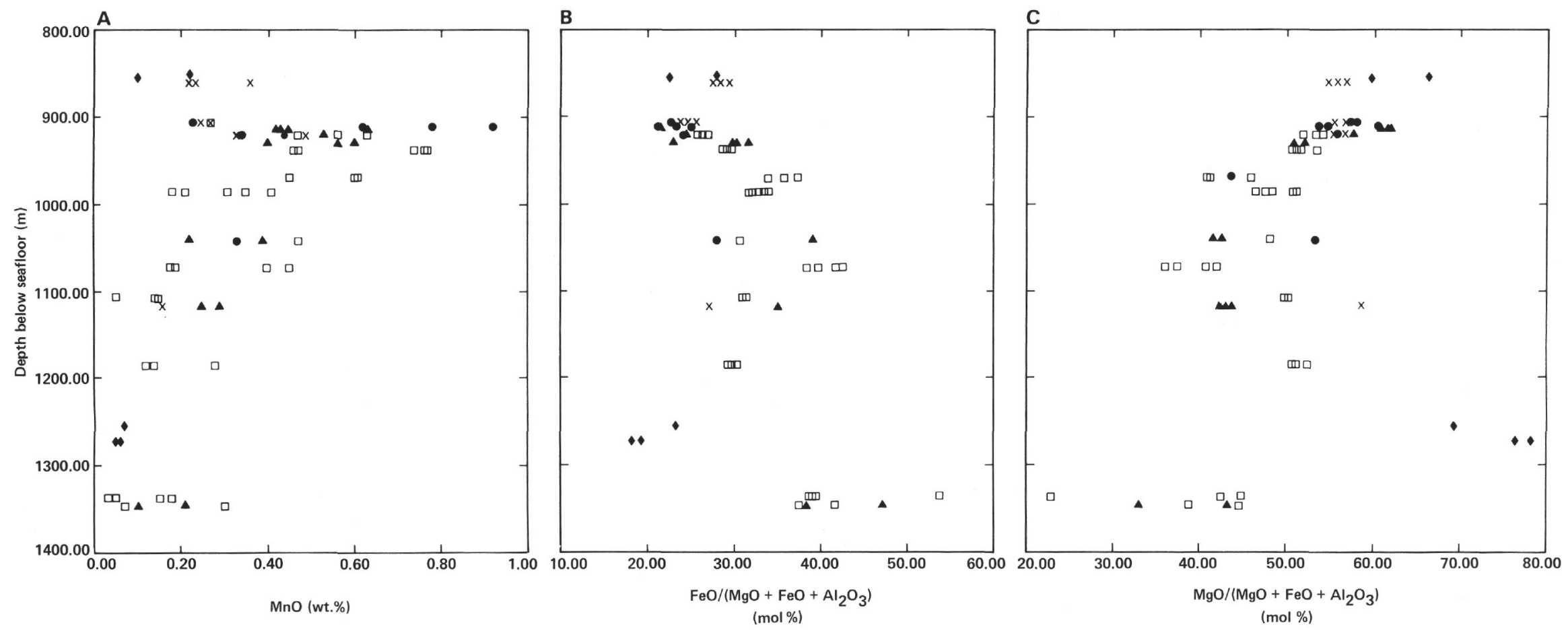

Figure 6. Compositions of clay minerals in Leg 83 basalts versus depth. (A) weight percent; (B) and (C) as mol percent. Symbols as in Figure 4. 
Table 12. Selected microprobe analyses of clay minerals, Hole 504B.

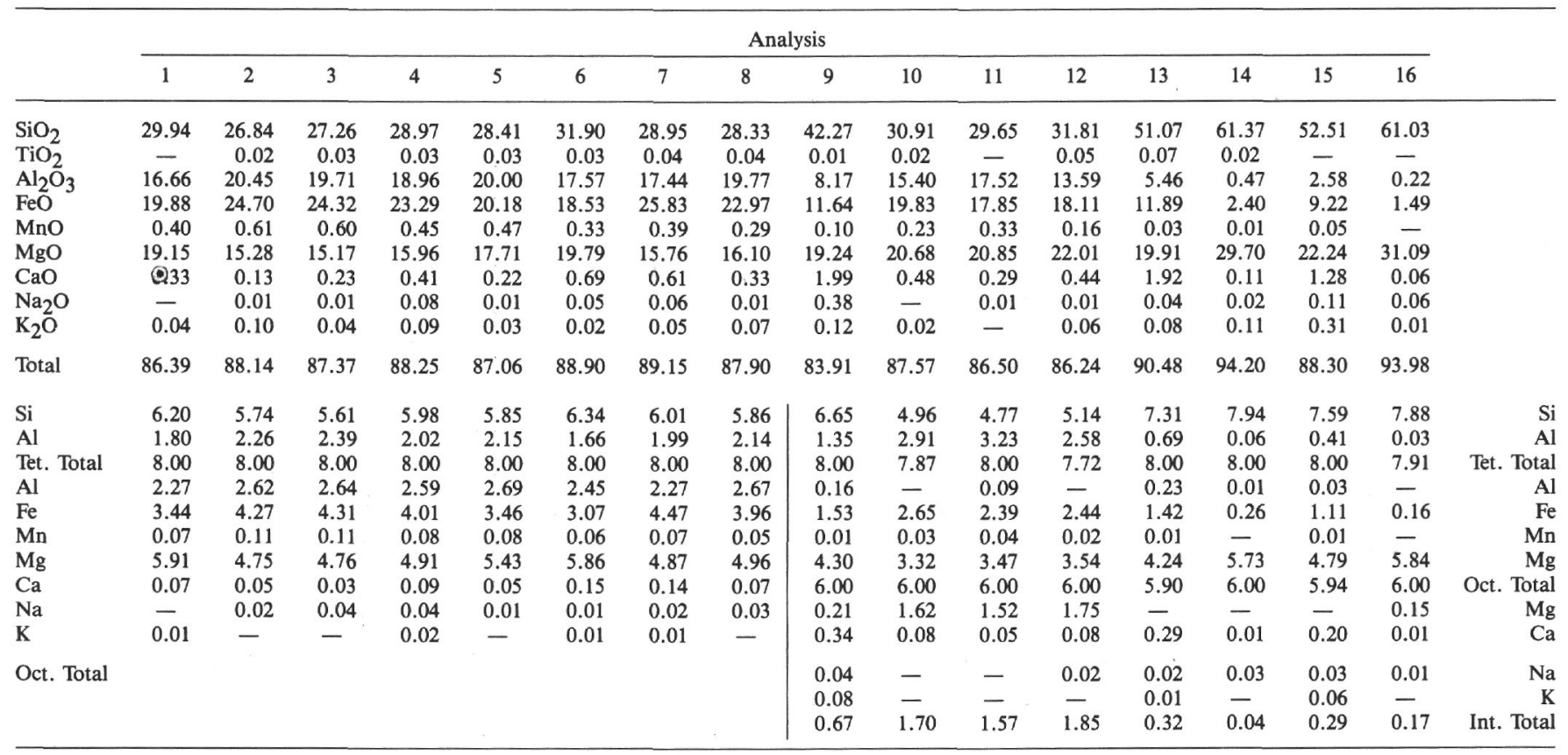

Note: 1 = Type 2 mixture in vein; Sample $82-1,46-49 \mathrm{~cm} .2$ = Chlorite in vein; Sample $87-1,116-123 \mathrm{~cm} .3=$ Chlorite replacing olivine phenocryst in light gray alteration halo adjacent to Analysis 5; Sample 87-1, 116-123 cm. 4 = Type 1 mixture replacing olivine phenocryst in host rock; Sample 87-1, 116-123 cm. $5=$ Chlorite in vein (+ replacing olivine phenocryst in adjacent alteration halo); Sample 94-1, 132-135 cm. 6 = Type 1 mixture replacing olivine phenocryst in host rock; Sample 94$1,132-135 \mathrm{~cm} .7=$ Type 2 mixture in vein; Sample $95-1,75-76 \mathrm{~cm} .8=$ Type 2 mixture replacing olivine phenocryst in alteration halo; Sample $104-2,48-55 \mathrm{~cm} .9=$ Vermiculite in vein with calcite and anhydrite; Sample 73-2, 29-32 cm. $10=$ Type 4 mixture in vein with anhydrite; Sample 74-1, 45-49 cm. $11=$ Type 4 mixture replacing olivine phenocryst; Sample $81-1,76-79 \mathrm{~cm} .12=$ Type 5 mixture replacing olivine phenocryst in host rock; Sample 104-2, 75-82 cm. $13=$ Type 5 mixture replacing olivine phenocryst; Sample 127-1, 109-112 cm. 14 = Talc associated with magnetite and clay mineral (analysis 13) replacing olivine; Sample 127-1, 109-112 $\mathrm{cm} .15=$ Type 4 mixture replacing olivine; Sample 129-2, 23-27 cm. 16 = Talc associated with magnetite and clay mineral (analysis 5) replacing olivine; Sample 129-2, 23-27 cm. Structural formulas for chlorite and Type 1 and 2 mixtures calculated based on 28 oxygens (Analyses 1-8); those for Type 4 and 5 mixtures, talc, and vermiculite based on 22 oxygens (Analyses 9-16).

Type 4 and 5 mixtures) replace the cores of the crystals from 1189 to $1319 \mathrm{~m}$ (Plate 6, Fig. 3.) Talc + magnetite occasionally occur at the center, or in a roughly concentric band within the pseudomorph, with the remainder consisting of chlorite-expandable clay mixtures.

Plagioclase is partly to totally altered, most commonly partly replaced by albite. Albite occurs as irregular patches, often only replacing cores of phenocrysts, with the igneous rims remaining intact. Albite boxwork pseudomorphs containing secondary void space totally replace phenocrysts in extensively altered rocks (Plate 1, Fig. 4) Microlites are generally less extensively altered than phenocrysts and are frequently unaltered. Heulandite is often associated with albite partially replacing plagioclase, occurring as irregular patches in igneous plagioclase, and either replacing remaining igneous plagioclase or filling secondary void space in albite boxwork pseudomorphs. Minor amounts of chlorite replace plagioclase throughout the hole along cracks or in small patches, occasionally associated with albite. Minor amounts of calcite and epidote also occasionally replace plagioclase, especially adjacent to calcite and epidote veins, respectively. Prehnite is common replacing plagioclase adjacent to quartz + epidote + laumontite veins in two samples from transition zone (Samples 504B-90-1, 69-72 cm and 504B-92-3, 112-113 cm) and is common in small amounts on the dike section.
From 1189 to $1319 \mathrm{~m}$ in the dike section, where talc + magnetite replace the outer rims of olivine phenocrysts, plagioclase is only sightly altered to chlorite. Scolecite is also fairly common replacing plagioclase in the dikes and in samples from the lowermost transition zone (Samples 504B-94-1, 132-135 cm and 504B-94-3, 67-72 cm).

Clinopyroxene generally appears unaltered to slightly corroded and cloudy from 898 to 967 m BSF, with very fine "dusty" opaque inclusions of secondary magnetite. Actinolite also occasionally occurs as overgrowths and reaction rims on pyroxenes adjacent to clay mineral veins and pseudomorphs after olivine phenocrysts (Plate 1, Fig. 3). From $967 \mathrm{~m}$ to the bottom of the hole $(1350 \mathrm{~m})$ magnetite is still present replacing pyroxene, and actinolite is much more common, generally as fibrous reaction rims but locally replacing entire crystals.

Titanomagnetite alteration ranges from slight corrosion and replacement by sphene around the edges of grains, along cracks, and in patches, to complete replacement by brownish, fine-grained aggregates of sphene. From 898 to $910 \mathrm{~m}$ BSF alteration of titanomagnetite varies widely in extent, whereas from 910 to the bottom of the transition zone $(1055 \mathrm{~m})$ titanomagnetite is generally extensively replaced by sphene and is locally slightly altered in less extensively altered rocks. Titanomagnetite is generally less extensively altered in the dike section than in the transition zone, but is locally completely altered. 
Glass at pillow rims was often not recovered, but glass in the several samples of pillow rims and breccias that were studied is always totally replaced by clay minerals and sphene. Phenocrysts in the glass are altered as in the host rock.

Pyrite is common disseminated in the rocks, where it replaces groundmass and phenocrysts in euhedral to irregular patches, up to $1.5 \mathrm{~mm}$ in size, often with unaltered silicate inclusions. Disseminated pyrite frequently forms irregular "stringers" aligned subparallel and 3-5 $\mathrm{mm}$ from clay mineral \pm quartz veins from 898 to 955 $m$ in the transition zone, and is often concentrated just outside centimeter-sized alteration halos around cracks.

\section{Wall Rock Alteration Zones}

Basalts throughout the section are often more extensively altered adjacent to veins, as shown by the lighter coloration frequently observed there (Plates 4 and 5). Alteration mineralogy and occurrence is generally the same in both zones, but the extent of alteration of primary phases is greater in the zone closer to the vein. Several samples from 928 to $946 \mathrm{~m}$ in the transition zone exhibit silicified zones up to $100 \mu \mathrm{m}$ wide adjacent to quartz + chlorite veins where wall rock is totally replaced by quartz, sphene, and minor chlorite (Plate 3, Fig. 2). Wall rock for up to 1 to $2 \mathrm{~mm}$ around chlorite + quartz \pm actinolite veins is often totally recrystallized to chlorite + sphene (+ actinolite below 967 m BSF) resulting in the millimeter-sized dark green alteration halos (Plate 4. Fig. 3).

Small rock fragments in breccias are more extensively altered than other rocks (Plate 4, Fig. 4). The fragments are nearly totally recrystallized to chlorite + quartz + sphene \pm actinolite. Clinopyroxene is the most resistant to alteration; occasionally only clinopyroxene remains unaltered or fragments of relict clinopyroxene remain in otherwise totally altered rocks. Relict igneous texture is often discernible, but occasionally fragments are so completely recrystallized that the original texture is not recognizable (e.g., Sample 504B-91-1, 47-50 cm).

A mineralized stockwork-like zone where pyrite, sphalerite, chalcopyrite, and minor galena occur with quartz in veins occurs in a highly altered pillow sequence from 910 to $928 \mathrm{~m}$ BSF within the transition zone (see Honnorez et al., this volume, for details).

Basalts from 1027 to $1336 \mathrm{~m}$ BSF in the dike section are characterized by the presence of centimeter-sized (up to $7 \mathrm{~cm}$ ) light greenish to gray-colored alteration patches, apparently unrelated to veins (Plate 5, Fig. 3). Primary minerals in the dark gray host rocks are generally little altered as described for the dike section in general, whereas the lighter-colored patches are more extensively altered. Within the extensively altered patches are irregulary shaped 0.3-1.5-mm-sized areas of chlorite + actinolite \pm laumontite and scolecite. In many cases these areas appear to be primary void (vug) fillings: chlorite and actinolite line the edges of these areas, and laumontite and actinolite fill the centers. No evidence of preexisting minerals is observed. However, in Sample 504B$133-1,34-43 \mathrm{~cm}, 0.3-0.6 \mathrm{~mm}$ patches of very fine-grained brownish material occur in addition to the void fillings and appear to be altered glassy or very fine-grained groundmass material.

Dikes from 1143 to $1336 \mathrm{~m}$ are in general less extensively altered than the basalts in the transition zone and upper dike sections, especially where talc + magnetite occur replacing olivine (1189-1319 m; Fig. 1; Plate 6, Fig. 3). Veins in these rocks are also much thinner and less abundant than in the overlying rocks.

Basalts recovered from 1336 to $1350 \mathrm{~m}$ are highly fractured and generally more extensively recrystallized than eleswhere in the dike section and are among the most altered rocks recovered from the hole (Plate 5, Fig. 2).

\section{Veins}

There are basically three stages of crack fillings in the transition zone and dike sections as determined by sequential crack fillings and cross-cutting relationships. These three stages are characterized by the most abundant minerals occurring at each stage: (1) clay minerals; (2) quartz + epidote; and (3) zeolites.

1. As the result of the first stage, clay minerals fill veins, often intergrown with pyrite and/or actinolite. Cross-cutting clay mineral veins are also occasionally observed (e.g., Samples 504B-79-2, 97-100 cm 504B-80-1, 101-116 cm). Pyrite often occurs disseminated along bands in the wall rock subparallel to and a few millimeters from these veins. More extensively altered wall-rock zones also occur adjacent to clay mineral veins. Quartz precedes clay mineral formation in several samples with silicified wall-rock zones from 928 to $955 \mathrm{~m}$ BSF in the transition zone. Fragments of early quartz and silicified wall rock are occasionally observed within later clay mineral veins (Plate 3. Fig. 2). In one sample (Sample 504B$133-2,34-43 \mathrm{~cm}$ ), albite occurs in a chlorite + actinolite vein as euhedral overgrowths on plagioclase crystals in the wall rock.

2. Quartz and epidote are the characteristic minerals of the second stage, occurring sequentially at the center of clay mineral-rimmed veins, in reopened clay veins, or cutting across clay veins (Plate 3, Figs. 1, 3; Plate 4, Figs. 1, 3). Quartz occurs alone in veins, but also commonly contains inclusions that constitute possibly a second generation of vermicular clay minerals. Epidote is frequently intergrown with quartz in veins of the transition zone and dike section (Plate 3, Fig. 1), but also occurs alone in the dike section. Actinolite needles are frequently included in both quartz and epidote. Pyrite is also fairly common in quartz + epidote veins in the transition zone. From 910 to $928 \mathrm{~m} \mathrm{BSF}$ in the transition zone pyrite, sphalerite, chalcopyrite, and minor amounts of galena occur intergrown with quartz \pm chlorite veins. These veins cut across earlier clay mineral veins and the disseminated pyrite bands in the wall-rock (see Honnorez et al., this volume, for details). Quartz is more abundant than epidote in the transition zone, whereas the proportions are reversed in the dike section. Both minerals are much less abundant in the dike section than in the transition zone. Albite also occasionally occurs in veins with epidote and quartz in the dike section.

3. The third stage of vein filling is characterized by the formation of zeolites, which fill remaining spaces be- 
tween quartz and epidote in cracks, cut across earlier veins, and occasionally partly replace quartz (Plate 1. Fig. 1; Plate 2; Plate 3, Figs. 1, 3, Plate 5, Fig. 2). Analcite is partly replaced by laumontite in Sample 504B-80$2,90-97 \mathrm{~cm}$ indicating that analcite formation preceded laumontite formation (Plate 2). Laumontite is by far the most abundant zeolite in veins. Heulandite occasionally occurs alone in small veins or as crystals lining the walls of laumontite veins, and nearly ubiquitously partly replaces quartz in veins reopened and filled with laumontite (Plate 3, Fig. 3). In the dike section laumontite and heulandite decrease in abundance, and scolecite is common down to about $1225 \mathrm{~m}$. Actinolite needles frequently occur as inclusions within all three minerals.

The relationship of scolecite and laumontite is not clear. Their occurrence in veins appears to be mutually exclusive: only one sample (Sample 504B-122-1, 88-95 $\mathrm{cm}$ ) contains both minerals. In this sample a 1-mm-wide laumontite vein pinches out, and after a $1-\mathrm{mm}$ transition, a millimeter-sized scolecite vein appears.

Anhydrite is a late mineral in veins, occurring at the center of clay mineral veins, and in two cases precedes laumontite formation. In Sample 504B-141-1, 58-61 cm anhydrite is partly replaced by laumontite, and in Sample 504B-74-1, 45-49 cm laumontite occurs interstitially between laths of anhydrite. Prehnite formation generally postdates zeolites and anhydrite formation in veins. It commonly partly replaces quartz laumontite, heulanditeepistilbite, albite, and anhydrite in veins and vugs (Plate 3, Fig. 4) and is especially abundant in veins at finegrained dike margins in the dike section. Scolecite is occasionally replaced by prehnite (e.g. Sample 504B-105$1,26-28 \mathrm{~cm}$ ), but in other cases the two minerals appear to be intergrown, and the relatioship is not clear (e.g., Samples 504B-99-1, 70-74 cm; 504B-106-1, 22-29 cm; 504B-114-1, 24-26 cm).

Calcite occurs filling remaining space in quartz veins in the upper transition zone and as monomineralic veinlets cutting across quartz and clay mineral veins. In Samples 504B-70-1, 106-111 cm; 504B-80-2, 91-97 cm; and 504B95-1, 54-59 cm following along cracks filled with calcite, the calcite terminates in a sharp contact against laumontite, which fills the remainder of the crack, suggesting the possibility that calcite and laumontite may have formed simultaneously.

Prehnite generally appears to be last mineral to form in veins, but in Samples 504B-111-1, 104-107 cm and 504B-116-1, 106-110 cm prehnite spherules appear to be corroded and partly replaced by clay minerals, suggesting a possible additional late stage of clay mineral formation locally.

\section{ISOTOPIC DATA}

\section{Oxygen Isotopic Ratios}

Isotopic data on calcite, quartz, epidote, and chlorite from veins in Leg 83 basalts are given in Table 13, along with new data on carbonates from the Leg 70 section of the hole. Note that the carbonate $\delta^{18} \mathrm{O}$ values decrease with depth, ranging from $+32 \%$. (SMOW) in Leg 70 pillow samples to $+9.6^{\circ} \%$ in Leg 83 transition zone. The
Table 13. Oxygen and carbon isotopic data for vein minerals in Hole 504B (Legs 70 and 83).

\begin{tabular}{lccc}
\hline $\begin{array}{c}\text { Sample } \\
\text { (interval in cm) }\end{array}$ & Mineral & $\begin{array}{c}\delta^{18} \mathrm{O} \\
\mathrm{SMOW}(\%)\end{array}$ & $\begin{array}{c}\delta^{13} \mathrm{C} \\
\mathrm{PDB}(\%)\end{array}$ \\
\hline Leg 70 & & & \\
& & & \\
$34-1,7-19$ & Calcite & +32.9 & -0.2 \\
$35-1,2-4$ & Calcite & +24.4 & -0.3 \\
$35-1,136-139$ & Calcite + aragonite & +28.7 & -0.2 \\
$37-1,36-38$ & Calcite & +28.7 & +0.3 \\
$37-3,32-34$ & Calcite & +31.5 & 0.0 \\
$40-3,130-135$ & Calcite & +28.0 & -0.1 \\
$53-1,3-5$ & Calcite & +23.7 & -1.8 \\
& & & \\
Leg 83 & & & \\
& & & \\
$73-2,29-32$ & Calcite & +10.0 & -2.5 \\
$79-3,147-149$ & Calcite & +18.0 & -7.7 \\
$80-1,30-32$ & Calcite & +9.6 & -6.1 \\
$80-1,106-111$ & Calcite & +10.6 & -5.1 \\
$80-1,106-111$ & Quartz & +11.1 & \\
$80-1,106-111$ & Chlorite & +1.3 & \\
$80-2,63-67$ & Calcite & +13.3 & -5.0 \\
$80-2,91-97$ & Calcite & +14.6 & -4.4 \\
$82-1,68-73$ & Calcite & +18.2 & -10.7 \\
$90-1,69-72$ & Quartz & +7.7 & \\
$90-1,69-72$ & Epidote & +2.5 & \\
$92-1,128-131$ & Calcite & +12.1 & -5.0 \\
$95-1,54-59$ & Calcite & +15.6 & -4.8 \\
\hline & & & \\
& & &
\end{tabular}

high $\delta^{18} \mathrm{O}$ values in the pillow section are indistinguishable from those obtained from carbonates in young DSDP basalts altered at near $0^{\circ} \mathrm{C}$. The low Leg $83 \mathrm{cal}-$ cite $\delta^{18} \mathrm{O}$ values are unusual for DSDP samples and are similar to values obtained from carbonates in dredged basalts (Muehlenbachs and Clayton, 1972; Stakes and O'Neil, 1982) and from ophiolites (Cocker et al., 1982).

Based on data from other natural hydrothermal systems, a temperature of $380^{\circ} \mathrm{C}$ is estimated from the quartz-epidote pair in Sample 504B-90-1, 69-72 cm (Hattori and Muehlenbachs, 1982). Water in equilibrium with this quartz at $380^{\circ} \mathrm{C}$ would have had a $\delta^{18} \mathrm{O}$ value of +2.5 to $3 \%$ (Clayton et al., 1972), suggesting that the fluids were evolved seawater that had gained ${ }^{18} \mathrm{O}$ through high-temperature exchange with basalts. However, using the experimentally determined quartz-zoisite fractionation yields a temperature of only about $270^{\circ} \mathrm{C}$ for the quartz-epidote pair (Matthews et al., 1983).

Fluid inclusion filling temperatures of $228-282^{\circ} \mathrm{C}$ have been determined in other quartz samples from Core 504B80 (Honnorez et al., this volume). At these temperatures, water in equilibrium with the quartz vein in Sample 504B$80-1,106-111 \mathrm{~cm}$ would have had a $\delta^{18} \mathrm{O}$ value of +1.0 to $+3.5 \%$ (Clayton et al., 1972). Such an ${ }^{18} \mathrm{O}$-rich water is incompatible with the $1.3 \% 0$ chlorite found in the same vein. Petrographic examination, however, shows that the chlorite predates the formation of quartz, and it is not unexpected that isotopic disequilibrium should be observed. The $\delta^{18} \mathrm{O}$ of $1.3 \%$ for the chlorite in Sample 504B-80-1, 106-111 cm is identical to that found in dredged submarine greenstones (Muehlenbachs and Clayton, 1972). It most likely formed from a fluid very near seawater composition at a temperature between 200 and $250^{\circ} \mathrm{C}$ (Hattori et al., 1980).

The oxygen isotope ratio of the vein carbonates in the transition zone does not appear to be in eqilibrium with 
the silicates either. The carbonates record temperatures of $86-190^{\circ} \mathrm{C}$ if they formed in equilibrium with unaltered seawater. However, a calcite from the stockworklike zone has a $\delta^{18} \mathrm{O}$ of $+9.65^{\circ} \%$ and a fluid inclusion filling temperature of $203-215^{\circ} \mathrm{C}$ (Honnorez et al., this volume; Table 13). The fluid in equilibrium with this calcite at this temperature would have had a $\delta^{18} \mathrm{O}$ of about $+0.8^{\circ} \%$ (O’Neil et al., 1969). This suggests that the calcites may have formed from ${ }^{18} \mathrm{O}$-enriched fluids at slightly higher temperatures $\left(94-215^{\circ} \mathrm{C}\right)$.

Bulk rock $\delta^{18} \mathrm{O}$ values range from +4.7 to $+8.9^{\circ} \%$ (SMOW; Table 14) and are similar to values reported for dredged submarine "greenstones" and metamorphosed pillows and dikes from ophiolites (Heaton and Sheppard, 1977; Muehlenbachs and Clayton, 1972; Cocker et al., 1982; Stakes and O'Neil, 1982). Leg 83 basalts exhibit variable changes in $\delta^{18} \mathrm{O}$ relative to the average unaltered submarine theoleiite $\left(\delta^{18} \mathrm{O}=+5.8^{\circ} \%\right)$. The bulk rock ${ }^{18} \mathrm{O}$ depletions are consistent with basalt-seawater reaction at high temperature $\left(\gtrsim 250^{\circ} \mathrm{C}\right)$, whereas the ${ }^{18} \mathrm{O}$ enrichments could have been produced either by reaction of the basalts with ${ }^{18} \mathrm{O}$-enriched fluids at similar temperatures or by reaction with seawater at slightly lower temperatures.

\section{Carbon Isotope Ratios}

Table 13 shows that the ${ }^{13} \mathrm{C}$ content of the vein carbonates systematically decreases with depth in Hole 504B. This most likely results from an influx of ${ }^{13} \mathrm{C}$-poor $\mathrm{CO}_{2}$ from the basaltic magmas $\left(\delta^{13} \mathrm{C} \simeq 7 \%\right.$, Pineau et al., 1976). Such low ${ }^{13} \mathrm{C}$ carbonates have also been observed in high-temperature discharge zones of the Macquarie Island ophiolite (Cocker et al., 1982). The only other alternative explanation is to suggest that dissolved organic matter in seawater has been flushed into these hydrothermal systems.

\section{DISCUSSION}

\section{Sequence and Conditions of Alteration}

The sequence and conditions of alteration of the Leg 83 basalts are interpreted in the following sections according to the same depth divisions described previously.

Table 14. Bulk rock oxygen isotopic data for Leg 83 basalts, Hole 504B.

\begin{tabular}{lcc}
\hline $\begin{array}{c}\text { Core-section } \\
\text { (interval in cm) }\end{array}$ & $\begin{array}{c}\text { Alteration } \\
\text { type }\end{array}$ & $\begin{array}{c}\delta^{18} \mathrm{O} \\
\text { (SMOW) }\end{array}$ \\
\hline $72-2,126-129$ & Dark gray & $+6.2 \%$ \\
$80-1,33-37$ & Light gray & +6.0 \\
$81-1,83-86$ & Altered glassy pillow rim & +5.1 \\
$91-1,66-70$ & Light gray wallrock & +8.9 \\
$91-1,66-70$ & Dark gray host rock & +5.9 \\
$94-1,132-135$ & Dark gray & +5.5 \\
$101-1,134-138$ & Brecciated dike margin & +5.2 \\
$104-2,67-72$ & $\quad$ Dark gray & +5.7 \\
$117-1,109-113$ & Light gray & +6.1 \\
$121-1,65-69$ & Light gray alteration & +6.5 \\
& halos around vugs & \\
$127-1,109-112$ & $\quad$ Dark Gray & +5.4 \\
$133-2,34-43$ & Green alteration "patch" & +5.4 \\
$133-2,34-43$ & Dark gray host rock & +4.7 \\
$141-1,67-71$ & Light green basalt & +5.3 \\
\hline
\end{tabular}

\section{Pillows and Upper Transition Zone (836-898 m)}

Clay minerals ( + rare quartz) were generally the first minerals to form in this section followed by calcite, zeolites, and anhydrite. This mineralogy and sequence are similar to those observed in the immediately overlying pillows, which are interpreted to have been altered at low water/rock ratios at temperatures of 60 to $110^{\circ} \mathrm{C}$ (Honnorez et al., 1983). Although clay minerals in the overlying pillows occasionally contain minor chlorite layers, they are predominantly smectite (Fig. 1). In contrast, the Leg 83 basalts lack pure smectite and contain chlorite-vermiculite-smectite mixtures. Sphene also occurs in Leg 83 rocks and is absent in the overlying pillows (Fig. 1). These observations plus the oxygen isotopic composition of calcites (Table 13) suggest higher temperatures of alteration in the Leg 83 section. The sequence of secondary mineral formation, from initial Mg-bearing clay minerals to later deposition of calcic phases, probably reflects the loss of magnesium from altering seawater fluids, possibly with a corresponding $\mathrm{pH}$ and $\mathrm{Ca}$ increase, as seen in experimental seawater-basalt reactions (Seyfried and Bishchoff, 1979, 1981).

\section{Transition Zone and Sheeted Dike Sections (898-1340 m)}

Alteration of basalts from $898-1350 \mathrm{~m}$ is interpreted to have occurred in three general stages based on the three stages of crack formation and secondary mineral formation (summarized in Fig. 7): (1) formation of chlorite, actinolite, pyrite, and sphene (and locally, early quartz) in veins, and greenschist-facies mineral parageneses in host rocks; (2) formation of quartz, epidote, and sulfides in veins; and (3) formation of mainly zeolites in veins and host rocks.

1. During the first alteration stage, the minerals forming were clay minerals, actinolite, pyrite, and sphene (and, locally, early quartz) in veins; these same minerals plus albite also replaced primary minerals and glass in the basalts. Fractures in recovered basalts appear to have been mostly sealed with clay minerals during this alteration stage.

Actinolite occurs in Icelandic hydrothermal systems at Krafla and in three other areas at measured and estimated temperatures of around $300^{\circ} \mathrm{C}(\mathrm{H}$. Kristmannsdottir, personal communication, 1983; Kristmannsdottir, 1975). In contrast, tremolite-actinolite has only formed in experimental seawater-basalt reactions at temperatures of $400^{\circ} \mathrm{C}$ or greater (Mottl and Holland, 1978; Hajash and Archer, 1980; Hajash and Chandler, 1981), although the mineralogy of these experimental run products is certainly influenced by kinetic effects (Mottl and Holland, 1978). The low $\delta^{18} \mathrm{O}$ value of a single clay mineral sample from Leg 83 basalts (Table 13) suggests formation from fluids close to seawater in composition at temperatures of $200-250^{\circ} \mathrm{C}$. These data indicate temperatures during the first stage of alteration of the transition zone and dike sections of at least $200-250^{\circ} \mathrm{C}$ and probably greater than $300^{\circ} \mathrm{C}$ where actinolite is present. The formation of abundant $\mathrm{Mg}$-rich clay minerals during this stage indicates the presence of Mg-bearing fluids, 


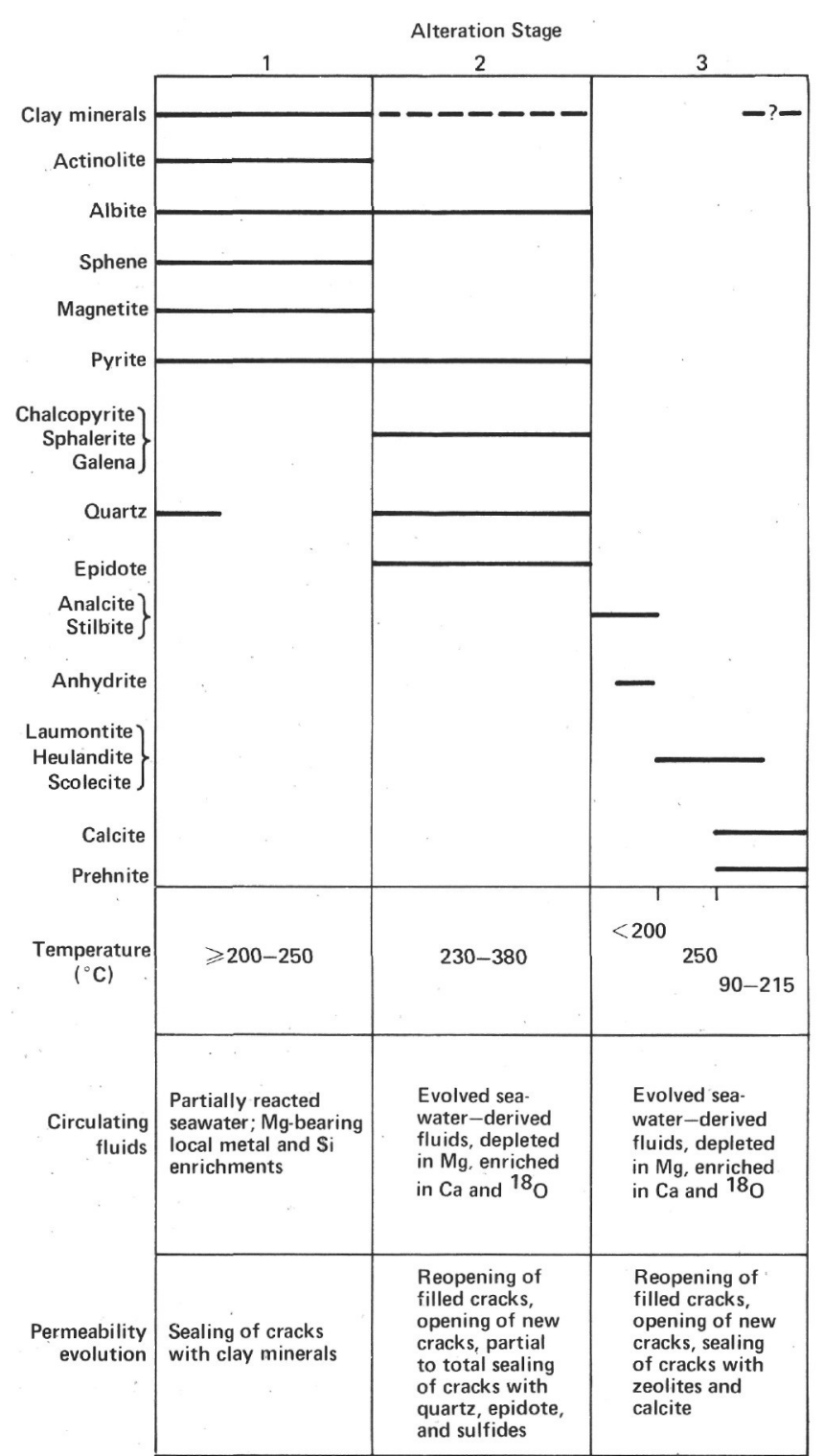

Figure 7. Summary diagram showing sequence of secondary mineral formation in Leg 83 basalts and interpreted conditions of formation. Alteration stages discussed in text.

possibly relatively unaltered seawater. However, some of the $\mathrm{Mg}$ in solution could have been released from the basalts, which in some cases have lost small amounts of $\mathrm{Mg}$ (Alt and Emmermann, this volume). Clay minerals are locally enriched in Mn and Fe (Fig. 6) suggesting somewhat evolved fluids. These clays may have formed from metal-enriched, Mg-bearing fluids produced by the partial reaction of seawater with basalt, as seen in the earliest states of experimental reactions (Seyfried and Mottl, 1982). The presence of silicified wall-rock zones and quartz replacing olivine from 914 to $955 \mathrm{~m}$ also suggests the presence of early envolved (Si-rich) fluids locally. Olivine can be replaced by chlorite + quartz by the introduction of only $\mathrm{H}_{2} \mathrm{O}, \mathrm{Fe}$, and $\mathrm{Al}$, but assuming that all of the $\mathrm{Si}$ from olivine goes into these phases, this process cannot account for the occasionally large volumes of quartz observed replacing olivine phenocrysts (about 40 vol. \%), and requires a source of $\mathrm{Si}$.

2. The second stage of alteration is characterized by reopening of veins filled with clay minerals during Stage 1 ; opening of new cracks cutting across clay veins; and the formation of quartz, epidote, and sulfides in veins (Plate 4, Figs. 1, 3, 4). The general lack of these phases replacing primary minerals in the basalts, as well as the lack of wall-rock alteration zones around Stage 2 veins, suggests that little or no alteration of the host rocks occurred during this stage. Filling temperatures of fluid inclusions in quartz associated with sulfides in the mineralized stockwork-like zone indicate temperatures of formation for quartz of $228-348^{\circ} \mathrm{C}$ (Honnorez et al., this volume). Oxygen isotopic data on quartz from these rocks suggest ${ }^{18} \mathrm{O}$ enrichment in the fluids of +1.0 to $+3.5 \%$ (Table 13; Clayton et al., 1972). Oxygen isotopic data for a quartz-epidote pair in Table 13 suggest temperatures of alteration of up to about $380^{\circ} \mathrm{C}$ and formation from seawater-derived fluids that may have been enriched in ${ }^{18} \mathrm{O}$ through high-temperature reaction with basalts. Both experimental and theoretical data predict that epidote should form in submarine hydrothermal systems at water-rock ratios less than about 35 , when $\mathrm{Mg}$ becomes rapidly depleted in solution and $\mathrm{pH}$ increases (Mottl, 1983; Reed, 1983). The Fe, Zn, Cn, and Pb sulfides that occur in the stockwork-like zone and locally elsewhere in the hole formed during the second alteration stage, indicating the Stage 2 solutions were at least locally enriched in metals. Combined with the isotopic data and general lack of $\mathrm{Mg}$-bearing clay minerals that formed during the second stage of alteration, these points suggest that the hydrothermal solutions were somewhat evolved (i.e., depleted in $\mathrm{Mg}$ and enriched in metals, silica and ${ }^{18} \mathrm{O}$ ). Variations in temperature and/or solution composition occurred within this second stage of alteration, as indicated by fluid inclusion data and sulfide mineral parageneses in the stockwork-like zone (Honnorez et al., this volume). Fractures were partly to totally sealed with quartz, epidote, and sulfides during this alteration stage.

Pyrites from the stockwork-like zone have $\delta^{34} \mathrm{~S}$ values of +2.9 to $+5.0 \%$ CDT (Cañon Diablo Troilite), indicating that sulfide-forming Stage 2 solutions contained a sulfide component derived in part from reduction of seawater sulfate (Honnorez et al., this volume). The secondary magnetite observed replacing clinopyroxene and olivine in Leg 83 basalts may be the result of oxidation of ferrous iron through reduction of seawater sulfate. Shanks et al. (1981) produced alteration assemblages similar to those observed replacing olivine from 1189 to 1319 $\mathrm{m}$ in Hole 504B by reacting fayalite with seawater at $350^{\circ} \mathrm{C}$ (experimental reaction products were talc, magnetite, hematite, and pyrite). The pyrite in these experiments was produced by reduction of seawater sulfate.

3. The third alteration stage is characterized by the reopening of earlier quartz and clay mineral veins, opening of new cracks cutting across quartz and clay mineral veins, and formation of zeolites in veins and in the host basalts. Analcite is partly replaced by laumontite, indi- 
cating that analcite formed first. Analcite originally formed in contact with quartz in Sample 504B-80-2, 90$97 \mathrm{~cm}$, and both phases are now partly replaced by laumontite (Plate 2). At temperatures greater than about $200^{\circ} \mathrm{C}\left(500\right.$ bars $\left.\mathrm{PH}_{2} \mathrm{O}\right)$ analcite should react with quartz to form albite (Liou, 1971a). The lack of reaction between adjacent quartz and analcite in this sample suggests that analcite may have formed at temperatures less than $200^{\circ} \mathrm{C}$. The presence of stilbite in a nearby sample also suggests lower temperatures, since stilbite breaks down to form laumontite and quartz at temperatures greater than about $150^{\circ} \mathrm{C}$ (500 bars $\mathrm{PH}_{2} \mathrm{O}$; Liou, 1971c). Both experimental reactions are reversible, indicating that they are equilibrium reactions. In contrast, basalts in Hole 504B record the effects of an open hydrothermal system characterized by disequilibrium among the various primary and secondary phases, suggesting that the application of the experimental data may not be valid.

Laumontite, scolecite, heulandite, and calcite are the next minerals to form. All these phases replace plagioclase and fill cracks. Fluid inclusions in analcite at the reaction front where analcite is being replaced by laumontite indicate that this reaction occurred at $250^{\circ} \mathrm{C}(350$ bars pressure; Honnorez et al., this volume). This temperature is above that at which laumontite reversibly dehydrates to form wairakite in experiments (measured $231^{\circ} \mathrm{C}$ at 500 bars $\mathrm{PH}_{2} \mathrm{O}$, est. $\sim 215^{\circ} \mathrm{C}$ at 350 bars; Liou, $1971 \mathrm{~b}$ ), suggesting (1) that wairakite originally replaced analcite at $250^{\circ} \mathrm{C}$ and then rehydrated to form laumontite as the system cooled below $231^{\circ} \mathrm{C}$ or (2) that laumontite formed metastably at $250^{\circ} \mathrm{C}$ replacing analcite. The general disequilibrium nature of the system and the lack of any relict wairakite suggest the latter alternative.

In Sample 504B-80-2, 90-97 cm quartz and analcite both extensively reacted with solution and were replaced by laumontite at $250^{\circ} \mathrm{C}$, whereas apparently no reaction occurred between adjacent analcite and quartz in the same sample. The lack of reaction between quartz and solution when analcite formed suggests that analcite may have formed in contact with quartz at lower temperatures, where reaction rates would be slower. This tends to support the experimental evidence that analcite and stilbite formed at relatively low temperatures (possibly less than $200^{\circ} \mathrm{C}$ ).

In regional metamorphic terranes, heulandite is generally considered to be a lower grade phase than laumontite (Coombs, 1971; Winkler, 1979). However, the temperature stability fields of heulandite and laumontite overlap, with heulandite formation being favored by higher silica activity (Boles and Coombs, 1977). This fits with the observed paragenesis of vein minerals in Leg 83 rocks, where laumontite fills reopened quartz veins, and heulandite partly replaces quartz in the same vein, where more silica was available through breakdown of the quartz. Fluctuations in silica activity of hydrothermal solutions may have controlled formation of laumontite-heulandite filling cracks.

All minerals formed during this stage of alteration (Fig. 7) would be favored by more evolved (rock-dominated) hydrothermal solutions, with depleted $\mathrm{Mg}$ and elevated $\mathrm{Ca}$ and $\mathrm{pH}$ relative to the earliest alteration stages.
Leg 83 calcites provide evidence for $\mathrm{Mg}$ depletion of hydrothermal fluids. Calcite precipitated from normal seawater at $25^{\circ} \mathrm{C}$ has a $\mathrm{Mg}$ content of about $8 \mathrm{~mole} \%$ (Mucci and Morse, 1983), and incorporation of $\mathrm{Mg}$ should increase with temperature (Fuchtbauer and Hardie, 1976). Calcites in Leg 83 basalts formed at temperatures up to $215^{\circ} \mathrm{C}$ (Table 13; Honnorez et al., this volume) and contain no detectable magnesium (Table 3), indicating formation from $\mathrm{Mg}$-depleted solutions. Fluid inclusion and oxygen isotopic data suggest that calcites formed from ${ }^{18} \mathrm{O}$-enriched fluids $(\sim+1 \%)$.

The range of calculated temperatures of formation of calcites $\left(\sim 90-215^{\circ} \mathrm{C}\right.$, Table 13$)$ suggests that: (1) they formed later than the zeolites, at lower temperatures; (2) they reequilibrated with later lower temperature solutions; or (3) zeolites and calcite formed at the same time over a range of temperatures. In some samples calcite appears to have formed simultaneously with the zeolites suggesting the latter two possibilities, whereas in other cases their relationships are not clear, allowing the first alternative.

Anhydrite is a late-forming mineral, often occurring with zeolites and calcite, suggesting formation from evolved hydrothermal fluids. However, Leg 83 anhydrites have $\delta^{34} \mathrm{~S}$ values of +21.2 to $+21.9 \%$ (CDT), similar to the seawater value $(+21 \% 0)$, indicating formation from seawater-derived solutions that had undergone little or no sulfate reduction and had not reacted significantly with basalt at high temperatures (Alt et al., this volume). This suggests introduction of relatively unaltered seawater into an evolving hydrothermal system at fairly high temperatures (i.e., zeolite facies mineral parageneses, temperatures up to $250^{\circ} \mathrm{C}$ based on the oxygen isotopic and fluid inclusion data previously discussed).

Prehnite is generally the last mineral to form in Leg 83 rocks; it replaces the Ca-zeolites, albite, plagioclase, quartz, and (locally) anhydrite, both in veins and in the basalts. Prehnite is less hydrous than the Ca-zeolites and generally forms at greater depths (higher $\mathrm{P}$ and $\mathrm{T}$ ) in regionally metamorphosed rocks (Coombs, 1971; Winkler, 1979). Stability fields of laumontite, heulandite, and prehnite overlap, however, with prehnite formation being favored by higher calcium to hydrogen ion activity ratios and by lower silica activity (Boles and Coombs, 1977). Further evolution of the hydrothermal fluid with resulting increased calcium activity and $\mathrm{pH}$, as observed in experimental seawater-basalt reactions (Seyfried and Mottl, 1982), could have led to the formation of prehnite in Leg 83 samples. Alternatively, an increase in temperature may also have caused late prehnite formation.

\section{Permeability Control of Alteration}

From 1189 to $1319 \mathrm{~m}$ in the dike section the basalts generally consist of dark gray, fresh-looking massive basalts and dikes. This interval is characterized by the presence of talc + magnetite intergrowths replacing olivine phenocrysts and generally little alteration of other phases. The number and size of cracks and veins in the rocks recovered from this interval is very small. Borehole televiewer records and the "clay content" log also indicate fewer and smaller fractures and less abundant $\mathrm{OH}$-bear- 
ing minerals, respectively, in this section of the hole than elsewhere (Anderson et al., 1982). Quartz, epidote, and calcite, which are common in veins in the overlying rocks, are essentially absent from this interval, and zeolite abundances are much lower. The fewer and narrower fractures from 1189 to $1319 \mathrm{~m}$ probably resulted in low primary permeability in this interval, restricting access of hydrothermal fluids and resulting in lower water-rock ratios.

Replacement of olivine by talc requires only addition of water and gain of silica or loss of magnesium, whereas formation of chlorite or smectite requires a source of aluminum as well. Thus, the replacement of olivine by talc (and magnetite) in this interval required only slight chemical changes, which fits with the suggested lower primary permeability and small extent of alteration of primary phases. The expandable components of clay minerals in this interval (and in the dike section in general) are less vermiculite rich than in the transition zone. This variability may also be related in some way to permeability of the basalts. The extensive fracturing and recrystallization of dikes from 1336 to $1350 \mathrm{~m}$, in contrast to the small extent of alteration in the overlying $\sim 150 \mathrm{~m}$ of basalts, indicate the heterogeneous nature of fracturing and alteration of the crust. This also suggests that the alteration of the crust is controlled by local zones of high permeability that focus the circulation of fluids.

\section{Relation of Leg 83 Section to Leg 69 and 70 Sections}

Based on the distribution of secondary minerals with depth in Hole 504B (Fig. 1), the section can be divided into three different depth zones with relatively sharp boundaries: the pillow section consists of the (1) upper (274.5$584.5 \mathrm{~m}$ ) and (2) lower (584.5-836 m) alteration zones, which are the result of various superimposed "low-temperature" (i.e., $\leq 110^{\circ} \mathrm{C}$ ) alteration processes (Honnorez et al., 1983), and (3) transition zone and dike sections (below $898 \mathrm{~m} \mathrm{BSF}$ ), which are generally characterized by greenschist and superimposed zeolite facies mineral parageneses.

Note that sphene appears, pure smectite disappears, and clay minerals become more chlorite rich and contain vermiculite near the top of the transition zone. Thus, a gradation exists from greenschist and zeolite facies parageneses in the transition zone and underlying dikes to "low-temperature" alteration in the overlying pillow section. A likely explanation for the clay mineral distribution in this interval is that the clays formed in a steep temperature gradient. Similar distributions of clay minerals from smectite to mixed-layer smectite-chlorite and chlorite with increasing alteration temperature have been observed in regional metamorphic areas and in subaerial hydrothermal systems, but over distances of hundreds to thousands of meters (Seki et al., 1969; Tómasson and Kristmannsdottir, 1972; Oki et al., 1974; Kristmannsdottir, 1976).

Some constraints can be placed on the timing of the alteration of the Leg 83 basalts. The high temperatures of alteration of the transition zone and dikes suggest the proximity of a magmatic heat source. The lack of any evidence for off-axis magmatism between the Costa Rica Rift and Site 504 indicates that magmatic activity at the spreading axis is the most likely heat source. Active venting of hydrothermal fluids (at temperatures of up to $\sim 350^{\circ} \mathrm{C}$ ) produced by reaction of seawater with basalts at high temperatures is restricted to a narrow zone, a couple of hundred meters wide, at spreading axes (Corliss et al., 1979; RISE Project Group, 1980; Michard et al., 1983). Low-temperature hydrothermal fluids $\left(\sim 15^{\circ} \mathrm{C}\right)$ also vent off-axis at the Galapagos hydrothermal mounds field, but there is no evidence to indicate that these fluids originated by high-temperature $\left(>100^{\circ} \mathrm{C}\right)$ reactions (Bender, 1983). At the spreading axis, the high-temperature isotherms $\left(\sim 350^{\circ} \mathrm{C}\right)$ locally reach the surface, but should rapidly sink beneath the seafloor away from the magma chamber, both along the axis and perpendicularly away from it (see figures in Kidd, 1977; Mottl, 1983). Thus, this discussion suggests that in the absence of off-axis magmatic activity the high-temperature alteration of the upper oceanic crust (and the Leg 83 transition zone and dike sections) should be restricted to very near the spreading axis (i.e., within a few kilometers). The repeated reopening of sealed fractures and the opening of new fractures observed in the Leg 83 basalts indicate that the rocks were being altered in a tectonically active area, possibly in the zone of extension close to the spreading axis, supporting the previous suggestion.

The three general stages of alteration of the transition zone and dike sections can be interpreted in terms of an evolving hydrothermal system, with (1) changes in solution composition due to reaction of seawater fluids with basalt at high temperatures $\left(\sim 150-400^{\circ} \mathrm{C}\right),(2)$ variations in permeability caused by several stages of sealing and opening of cracks, and (3) a general cooling of the system, caused either by the cooling of a magma chamber beneath the spreading center and/or the movement of the crust away from the heat source. Late in the sequence a pulse of relatively unaltered seawater entered the system, resulting in the local formation of small amounts of anhydrite, followed by continuing evolution of the system. The transition zone basalts are enriched in $\mathrm{Mn}$ and S (Alt and Emmermann, this volume) and contain a metal-sulfide-rich, stockwork-like zone, suggesting that they were altered in a hydrothermal upflow zone.

Honnorez et al. (1983) proposed a "simple but purely hypothetical" model for the alteration of the pillow section at Site 504 (274.5-836 m): (1) celadonite-nontronite formed in cracks and adjacent basalts from low-temperature hydrothermal fluids in the upper alteration zone (274.5-584.5 m); (2) iron-hydroxide-bearing mixtures ("iddingsite") mainly replaced olivine by reaction of the basalts with cold oxygenated seawater as it percolated through the upper alteration zone; (3) basalts throughout the pillow section reacted either with seawater at low water-rock ratios or with evolved seawater resulting in the formation of saponite and pyrite in both upper and lower alteration zones (274.5-836 m); and (4) $\mathrm{Na}$ and $\mathrm{Na}-\mathrm{Ca}$ zeolites formed in newly opened cracks and adjacent wall rock in the zeolite zone from 528.5 to $563 \mathrm{~m}$, and locally in veins in the lower alteration zone (below $584.5 \mathrm{~m}$ ).

How then can the high-temperature alteration observed in the transition zone and dike sections be related to the 
lower temperature alteration in the pillow sections of the crust? The alteration sequences are well documented within the different depth intervals in the section, but the relationships among the different zones remain obscure. Some possible scenarios are given.

One possibility is that the metamorphism of the transition zone and dikes occurred close to the spreading axis beneath the existing $571 \mathrm{~m}$ pillow pile. The change in mineralogy from 836 to $898 \mathrm{~m}$ in the section may be due to a steep temperature gradient from high-temperature fluids in the transition zone and dike sections to lower temperature solutions circulating in the overlying, probably highly permeable pillow pile. Alteration might have been occurring in a relatively open seawater system in the upper alteration zone resulting in the formation of celadonite-nontronite and iddingsite, while saponite and pyrite formed under more restricted conditions in the lower alteration zone, and the first alteration stages (producing greenschist facies parageneses) were occurring in the underlying transition zone and dikes. Circulation eventually became more restricted in the upper alteration zone, resulting in the later formation of saponite and pyrite in these rocks. This may have been caused by sealing of the basement by sediment and the cessation of open convection of seawater through the upper crust. Evolution of solution composition occurred throughout the section resulting in the formation of zeolites and calcite late in the paragenetic sequence. The distribution of zeolites in the hole (from $\mathrm{K}-\mathrm{Na}$ to $\mathrm{Na}-\mathrm{Ca}$ to $\mathrm{Ca}$-zeolites with increasing depth) may have been in response to a temperature gradient, although evolution of fluid compositions and formation of zeolites may have occurred at significantly different rates and times in the various zones.

On the other hand, if alteration of the transition zone and dike rocks occurred within the narrow zone of the dike injection at the spreading axis, the surface of the basement may have been within or near the top of the transition zone at the time of metamorphism (see Kidd, 1977). In this case the gradation in mineralogy near the top of the transition zone may be due to a steep temperature gradient from high-temperature hydrothermal fluids in the basement to overlying cold seawater. The formation of the metal-sulfide-rich, stockwork-like mineralization near the top of the transition zone during alteration Stage 2 might be analogous to the subsurface mixing of hydrothermal fluids with seawater and sulfide deposition interpreted to be occurring at the axis of the Galapagos Spreading Center (Edmond et al., 1979). As the crust moved away from the axis, the transition zone and dike basalts altered at high temperature would then have been buried by subsequent basalt pillows and massive flows. It is possible that the high-temperature alteration of the transition zone and dike sections at the spreading axis in this case could have reduced their permeability sufficiently so that the alteration of the overlying pillows might have occurred later in a shallow, low-temperature hydrothermal system with circulation restricted to the pillow section.

There are many arguments for and against both the general cases presented previously and the details within each case. However, it is not possible with the present evidence to make a choice between either of these or among any other alternatives.

\section{CONCLUSIONS}

Alteration of basalts in the upper alteration zone $(274.5-584.5 \mathrm{~m})$ in the pillow section initially occurred in a relatively open system, resulting in the formation of mainly celadonite-nontronite and "iddingsite." This was followed by more restricted conditions and the formation of saponite in these rocks. Alteration of basalts in the lower alteration zone (584.5-836 m) in the pillow section occurred under anoxic conditions at probably low water-rock ratios and is characterized by the presence of saponite and pyrite. Zeolites, calcite, and minor anhydrite formed late in the alteration sequence. Temperatures of alteration throughout the pillow section were probably less than about $100^{\circ} \mathrm{C}$.

Alteration of the uppermost pillows and transition zone in the Leg 83 section (836-898 m) occurred under conditions similar to those governing alteration in the immediately overlying pillow section (anoxic, low water/ rock ratio), but probably at higher temperatures $\left(>100^{\circ} \mathrm{C}\right)$. Evolution of fluid composition resulted in the sequence: (1) clay minerals; and (2) zeolites, anhydrite, and calcite.

Alteration of basalts in the transition zone and dike sections (898-1350 m BSF) occurred in three basic stages, defined by the opening of fractures and the formation of characteristic secondary minerals. (1) Chlorite, actinolite, pyrite, albite, sphene, and minor quartz formed in veins and host basalts from partially reacted seawater (Mg-bearing, locally metal- and Si-enriched) at temperatures of at least $200-250^{\circ} \mathrm{C}$. (2) Quartz, epidote, and sulfides formed in veins at temperature of up to $380^{\circ} \mathrm{C}$, from more evolved (Mg-depleted, metal-, $\mathrm{Si}$-, and ${ }^{18} \mathrm{O}$ enriched) fluids. (3) The last stage is characterized mainly by zeolite formation: (a) analcite and stilbite formed locally, possibly at temperatures less than $200^{\circ} \mathrm{C}$, followed by (b) formation of laumontite, heulandite, scolecite, calcite, and prehnite from solutions depleted in $\mathrm{Mg}$ and enriched in $\mathrm{Ca}$ and ${ }^{18} \mathrm{O}$ at temperatures of up to $250^{\circ} \mathrm{C}$. The presence of small amounts of anhydrite locally may be due to ingress of relatively unaltered seawater into the system during Stage 3.

Alteration is characterized by generally incomplete recrystallization of primary phases and replacement reactions among secondary minerals. Secondary mineralogy in the host basalts is strongly controlled by primary mineralogy.

Carbonate $\delta^{18} \mathrm{O}$ and $\delta^{13} \mathrm{C}$ values decrease from the pillow section to the transition zone, indicating higher temperatures of alteration in the transition zone and suggesting an influx of ${ }^{13} \mathrm{C}$-poor $\mathrm{CO}_{2}$ from basaltic magma.

Primary permeability of the crust controlled the extent of alteration of the basalts. Less permeable massive dikes in the central part of the recovered dike section are less extensively altered than the more highly fractured transition zone basalts and the lowermost dikes.

The alteration of the transition zone and dike sections can be interpreted in terms of an evolving hydro- 
thermal system, with (a) changes in solution composition due to reaction of seawater fluids with basalts at high temperatures; (b) variations in permeability caused by several stages of sealing and reopening of cracks; and (c) a general cooling of the system, caused either by the cooling of a magma chamber beneath the spreading center and/or the movement of the crust away from the heat source. The transition zone basalts are enriched in $\mathrm{Mn}$ and S and contain a metal sulfide-rich, stockworklike zone, suggesting that they were altered in a hydrothermal upflow zone. The relationship of the high-temperature alteration in the transition zone and dike sections to the low-temperature alteration in the overlying pillow section remains uncertain.

\section{ACKNOWLEDGMENTS}

J. C. A. thanks J. Honnorez for the opportunity to participate on Leg 83 and for many thoughtful discussions, and J. Nelen, E. Jarosewich, and W. Melson for use of the microprobe and assistance with analyses. J. C. A.'s contribution was supported by NSF Grant OCE81-17698 to J. Honnorez.

C. L. acknowledges the financial assistance of ATP GGO No. 98249 and expresses thanks to Marcel Bohn, Henri Bougault, and Catherine Mevel. K. M.'s contribution was supported by the Canadian National Science and Engineering Research Council.

The authors also thank Paul Robinson and Hubert Staudigel for reviewing the manuscript. Contribution from the Rosenstiel School of Marine and Atmospheric Science, University of Miami.

\section{REFERENCES}

Anderson, R. N., Honnorez, J., Becker, K., Adamson, A. C., Alt, J. C., Emmerman, N. R., Kempton, P. D., Kinoshita, H., Laverne, C., Mottl, M. J., and Newmark, R. L., 1982. DSDP Hole 504B, the first reference section over $1 \mathrm{~km}$ through Layer 2 of the oceanic crust. Nature, 300:589-594.

April, R. H., 1980. Regularly interstratified chlorite/vermiculite in contact methamorphosed red beds, Newark Group, Connecticut Valley. Clays Clay Minerals, 28:1-11.

Becker, K., Langseth, M. G., Von Herzen, R. P., and Anderson, R. N., 1983. Deep crustal geothermal measurements Hole 504B, Costa Rica Rift. J. Geophys. Res., 88:3447-3457.

Bender, M. L., 1983. Pore water chemistry, Sites 506-509, Deep Sea Drilling Project In Honnorez, J., Von Herzen, R. P., et al., Init. Repts. DSDP, 70: Washington (U.S. Govt. Printing Office), 343-354.

Boles, J. R., and Coombs, D. S., 1977. Zeolite facies alteration of sandstones in the southland syncline, New Zealand. Am. Sci., 277: 982-1012.

Brindley, G. W., and Brown, G., 1980. Crystal Structures of Clay Minerals and Their $X$-ray Identification: London (Mineralogical Soc. London).

Cann, J. R., Langseth, M. G., Honnorez, J., Von Herzen, R. P., White, S. M., et al., 1983. Init. Repts. DSDP, 69: Washington (U.S. Govt. Printing Office).

Clayton, R. N., O’Neil, J. R., and Mayeda, T. K., 1972. Oxygen isotope exchange between quartz and water. J. Geophys. Res., 77: 3057-3067.

Cocker, J. D., Griffin, B. J., and Muehlenbachs, K., 1982. Oxygen and carbon isotope evidence for seawater-hydrothermal alteration of the Macquarie Island ophiolite. Earth Planet. Sci. Lett., 61: 112-122.

Coombs, D. S., 1952. Cell size, optical properties, and chemical composition of laumontite and leonhardite. Am. Mineralogist 37: 812-830.

1971. Present status of the zeolite facies. Molecular Sieve Zeolites I. Am. Chem. Soc., pp. 317-327.

Corliss, J. B., Dymond, J., Bordon, L. I., Edmond, J. M., Von Herzen, R. P., Ballard, R. D., Green, K., Williams, D., Brainbridge, A., Crane, K., and van Andel, T. H., 1979. Submarine thermal springs on the Galapagos Rift. Science, 203:1073-1083.
Deer, W. A., Howie, R. A., and Zussman, J., 1964. Rock Forming Minerals (Vols. 1-4): New York (Wiley and Sons).

Edmond, J. M., Measures, C., McDuff, R. E., Chan, L. J., Collier, R., Grant, B., Gordon, L. I., and Corliss, J. B., 1979. Ridge Crest hydrothermal activity and the balances of the major and minor elements in the ocean: the Galapagos data. Earth Planet. Sci. Lett., 46:1-18

Foster, M. D., 1965. Composition of zeolites of the natrolite group. USGS Prof. Paper 504-D, pp. 1-7.

Fuchtbauer, H., and Hardie, L. A., 1976. Experimentally determined homogeneous distribution coefficients for precipitated magnesian calcites: application to marine carbonate cements. (Abstract) Geol. Soc. Am. Ann. Mtg., Abstr. Progr., 8:877.

Goldsmith, J. R., Graf, D. L., and Heard, H. C., 1961. Lattice constants of the Ca-Mg carbonates. Am. Mineralogist, 46:453-457.

Hajash, A., and Archer, P., 1980. Experimental seawater/basalt interactions: effects of cooling. Contrib. Mineral. Petrol., 75:1-13.

Hajash, A., and Chandler, G. W., 1981. An experimental investigation of high-temperature interactions between seawater and rhyolite, andesite, basalt and peridotite. Contrib. Mineral. Petrol., 78: 240-254.

Harrison, C. G. A., 1981. Magnetization of the oceanic crust. In Emiliani, C. (Ed.), The Sea (Vol. 7): New York, (John Wiley and Sons), 219-240.

Hattori, K., and Muehlenbachs, K., 1982. Oxygen isotope ratios of the Icelandic crust. J. Geophys. Res., 87:6559-6565.

Hattori, K., Urabe, T., and Muehlenbachs, K., 1980. Anhydrite bodies of marine hydrothermal origin at Kuroko. Third Int. Water Rock Inter. Conf., Edmonton, pp. 24-26.

Heaton, T. H. E., and Sheppard, S. M. F., 1977. Hydrogen and oxygen isotope evidence for seawater-hydrothermal alteration and ore deposition, Troodos Complex, Cyprus. In Volcanic Processes in Ore Genesis: London (Inst. Mining and Metallurgy), Geol. Soc. London, pp. 42-47.

Hey, M. H., 1954. A new review of the chlorites, Min. Mag., 30:277.

Honnorez, J., Laverne, C., Hubberten, H., Emmermann, R., and Muehlenbachs, K., 1983. Alteration processes of Layer 2 basalts from Deep Sea Drilling Project Hole 504B, Costa Rica Rift. In Cann, J. R., Langseth, M. G., Honnorez, J., Von Herzen, R. P., White, S. M., et al., Init. Repts. DSDP, 69, Washington (U.S. Govt. Printing Office), 509-546.

Houtz, R., and Ewing, J. I., 1976. Upper crustal structure as a function of plate age. J. Geophys. Res., 81(14):2490-2498.

Kidd, R. G., W., 1977. A model for the process of formation of the upper oceanic crust. Geophys. J. R. Astr. Soc., 50:149-148.

Kristmannsdottir, H., 1975. Hydrothermal alteration of basaltic rocks in Icelandic geothermal areas. Second U.N. Symp. on the Development and Utilization of Geothermal Resources: San Francisco, pp. 441-445.

1976. Types of clay minerals in hydrothermally altered basaltic rocks, Reykjanes, Iceland. Jökull, 26:30-39.

Laverne, D., 1983. Occurrence of melanite and aegirine-augite in Deep Sea Drilling Project Hole 504B. In Cann, J. R., Langseth, M. G., Honnorez, J., Von Herzen, R. P., White, S. M., et al., Init. Repts. $D S D P$, 69: Washington (U.S. Govt. Printing Office), 593-606.

Leake, B. E., 1978. Nomenclature of amphiboles. Am. Mineralogist, 63:1023-1053.

Liou, J. G., 1971a. Analcime equilibria. Lithos, 4:389-402.

1971b. P-T stabilities of laumontite, wairakite, lawsonite, and related minerals in the system $\mathrm{CaAl}_{2} \mathrm{Si}_{2} \mathrm{O}_{8}-\mathrm{SiO}_{2}-\mathrm{H}_{2} \mathrm{O}$. J. Petrol., 12:370-411.

,1971c. Stilbite-laumontite equilibria. Contrib. Mineral. Petrol., 31:171-177.

Martin-Vivaldi, J. L. M., and MacEwan, D. M. C., 1960. Corrensite and swelling chlorite. Clay. Mineral. Bull., 3:177-183.

Mattews, A., Goldsmith, J. R., and Clayton, R. N., 1983. Oxygen isotope fractionation between zoisite and water. Geochim. Cosmochim. Acta, 47:645-654.

Michard, A., Albarède, F., Michard, G., Minster, J. F., and Charlou, J., 1983. Rare-earth elements and uranium in high-temperature solutions from East Pacific Rise hydrothermal vent field $\left(13^{\circ} \mathrm{N}\right) . \mathrm{Na}$ ture, 303:795-797.

Mottl, M. J., 1983. Metabasalts, axial hot springs, and the structure of hydrothermal systems at mid-ocean ridges. Geol. Soc. Am. Bull, , 94:161-180. 
Mottl, M. J., and Holland, H. D., 1978. Chemical exchange during hydrothermal alteration of basalt by seawater-I. Experimental results for major and minor components of seawater. Geochim. Cosmochim. Acta, 42:1103-1115.

Mucci, A., and Morse, J. W., 1983. The incorporation of $\mathrm{Mg}$ and $\mathrm{Sr}$ into calcite overgrowths: influences of growth rate and solution composition. Geochim. Cosmochim. Acta, 47:217-233.

Muehlenbachs, K., and Clayton, R. N., 1972. Oxygen isotope geochemistry of submarine greenstones. Can. J. Earth Sci., 9:471-478.

Oki, Y., Hirano, T., and Suzuki, T., 1974. Hydrothermal metamorphism and vein minerals of the Yugawara geothermal area, Japan. Water Rock Interaction: Prague (Geol. Survey), pp. 81-94.

O'Neil, J. R., Clayon, R. N., and Mayeda, T. K., 1969. Oxygen isotope fractionation in divalent metal carbonates. J. Chem. Phys., 51:5547-5558.

Pineau, F., Javoy, M., and Bottinga, Y., $1976 .{ }^{13} \mathrm{C} /{ }^{12} \mathrm{C}$ ratios of rocks and inclusions in popping rocks of the Mid-Atlantic Ridge and their bearing on the problem of isotope composition of deep seated carbon. Earth Planet. Sci. Lett., 29:413-421.

Reed, M. H., 1983. Seawater-basalt reaction and the origin of greenstones and related ore deposits. Econ. Geol., 78:466-485.

RISE Project Group, 1980. East Pacific Rise: hot springs and geophysical experiments. Science, 207:1421-1433.

Seki, Y., Oki, Y., Matsuda, T., Mikami, K., and Okumura, K., 1969. Metamorphism in the Tantawa Mountains, Central Japan. J. Assoc. Jap. Min. Petrol. Econ. Geol., 61:1-25, 30-75.
Seyfried, W. E., and Bischoff, J. L., 1979. Low temperature basalt alteration by seawater: an experimental study at $70^{\circ} \mathrm{C}$ and $150^{\circ} \mathrm{C}$. Geochim. Cosmochim. Acta, 43:1937-1947.

, 1981. Experimental seawater-basalt interaction at $300^{\circ} \mathrm{C}$, 500 bars, chemical exchange, secondary mineral formation, and implications for the transport of heavy metals. Geochim. Cosmochim. Acta, 45:135-147.

Seyfried, W. E., and Mottl, M. J., 1982. Hydrothermal alteration of basalt by seawater under seawater-dominated conditions. Geochim. Cosmochim. Acta, 46:985-1002.

Shanks, W. C., Bischoff, J. L., and Rosenbauer, R. J., 1981. Seawater sulfate reduction and sulfur isotope fractionation in basaltic systems: Interaction of seawater with Fayalite and Magnetite at 200$350^{\circ} \mathrm{C}$. Geochim. Cosmochim. Acta, 45:1977-1995.

Stakes, D. S., and O'Neil, J. R., 1982. Mineralogy and stable isotope geochemistry of hydrothermally altered oceanic rocks. Earth Planet. Sci. Lett., 57:285-304.

Stephen, I., and MacEwan, D. M. C., 1950. Swelling chlorites. Geotechnique, 2:82-83.

Tómasson, J., and Kristmannsdottir, H., 1972. High temperature alteration minerals and thermal brines, Reykjanes, Iceland, Contrib. Mineral. Petrol., 36:123-134.

Winkler, H. G. F., 1979. Petrogenesis of Metamorphic Rocks: New York (Springer-Verlag).

Date of Initial Receipt: 25 April 1983

Date of Acceptance: 18 November 1983 

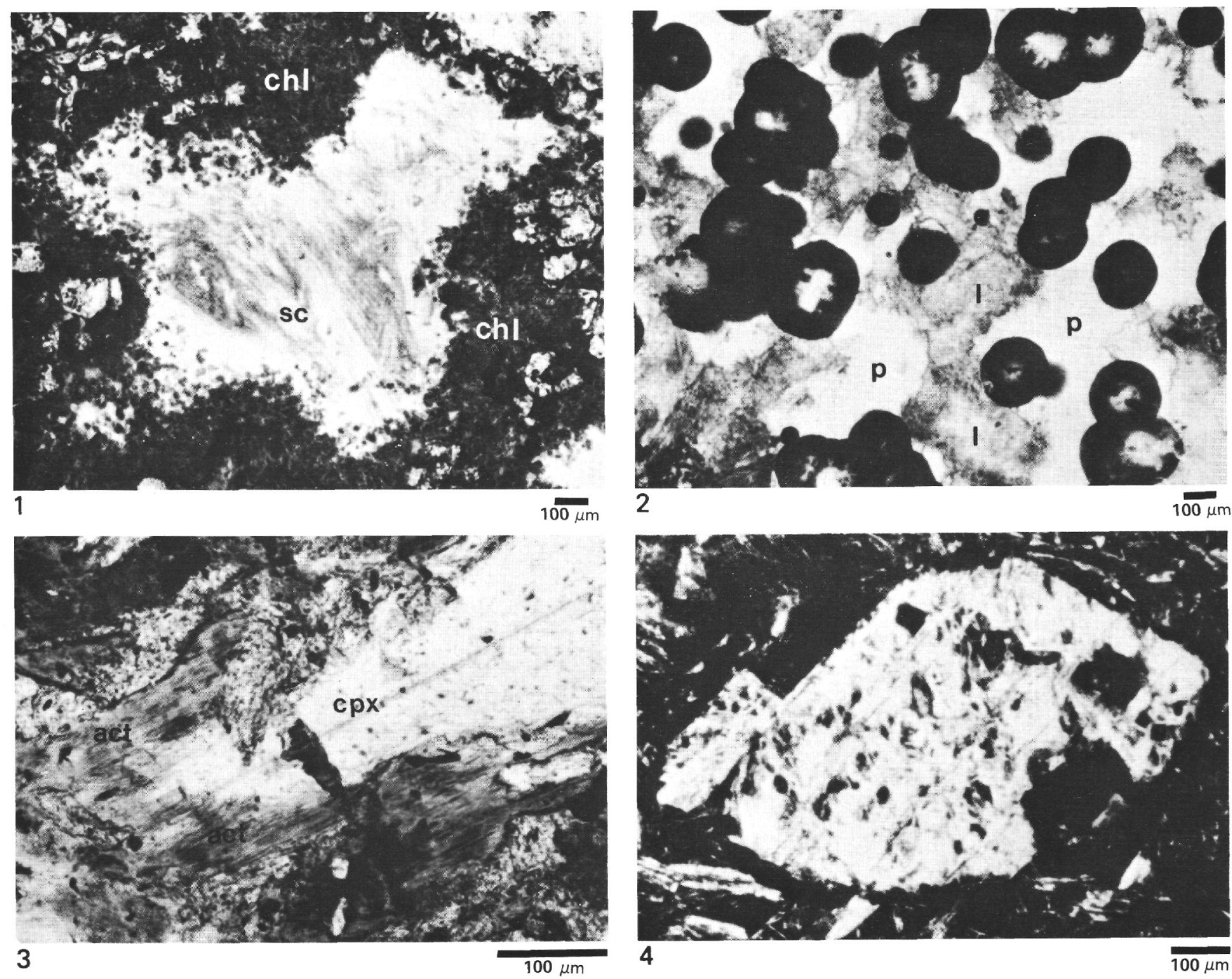

Plate 1. Photomicrographs of secondary minerals in Leg 83 basalts. 1. Vug filled with chlorite (chl) at edge and fibrous scolecite (sc) at the center. Plane polarized light. Sample 504B-102-1, 24-30 cm. 2. Clear euhedral prehnite prisms surrounded by fibrous prehnite spherules (black), with clear sheaflike prehnite (white, p) and laumontite (gray, l). Plane light. Sample 504B-111-1, 104-107 cm. 3. Clinopyroxene phenocryst (cpx) partly replaced by reaction rim of fibrous actinolite (act). Plane light. Sample 504B-100-1, 14-18 cm. 4. Plagioclase phenocryst totally replaced by albite. Crossed polars. Sample 504B-80-3, 133-119 cm. 

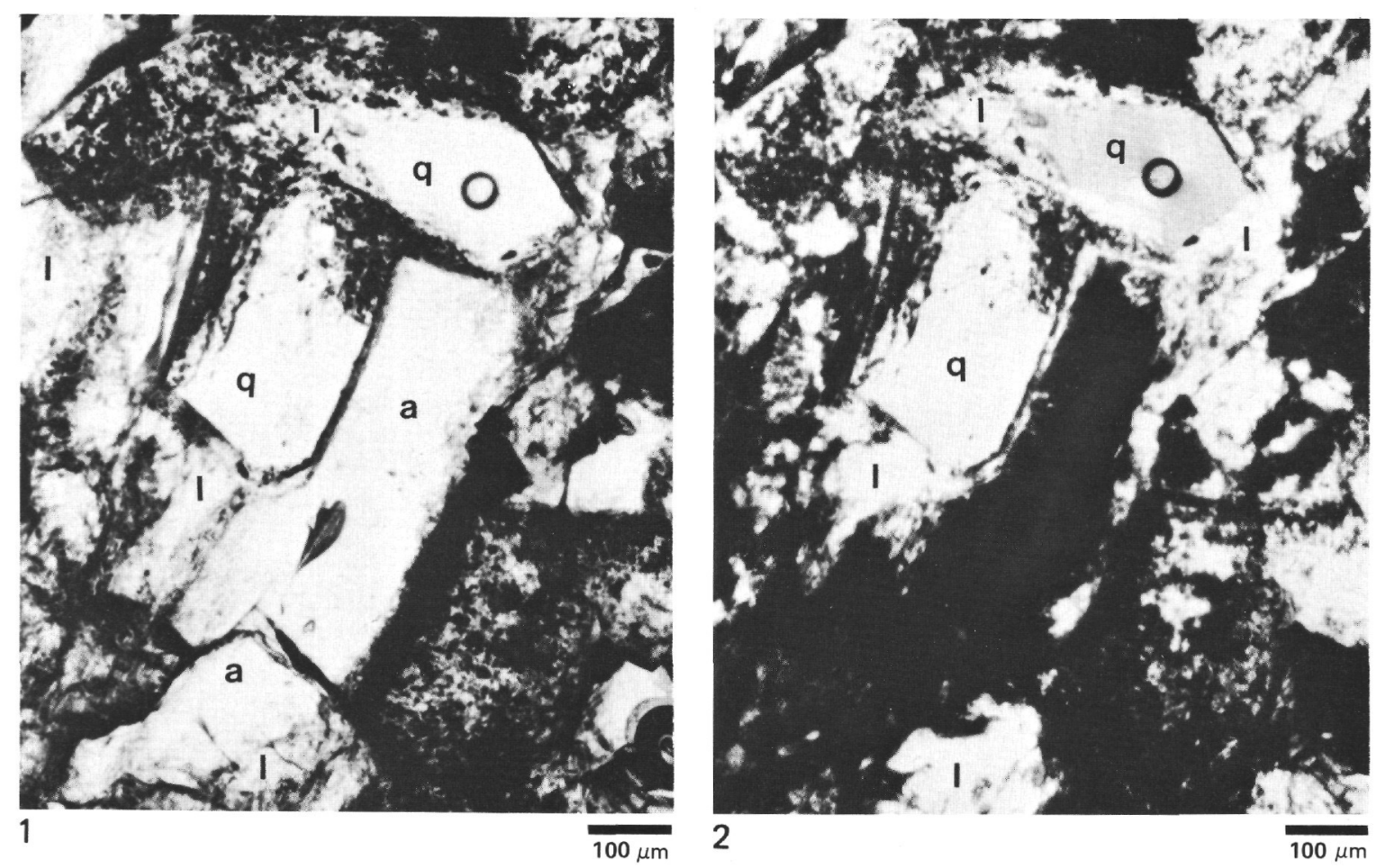

Plate 2. Photomicrographs of analcite in Sample 504B-80-2, 91-97 cm. 1. Quartz (q) and analcite (a) partly replaced by laumontite (1) in vein through former glassy pillow rim. Mottled areas are altered glass fragments. Circle in euhedral quartz is a bubble in the thin section. Plane light. 2. Same as Fig. 1, crossed polars. 


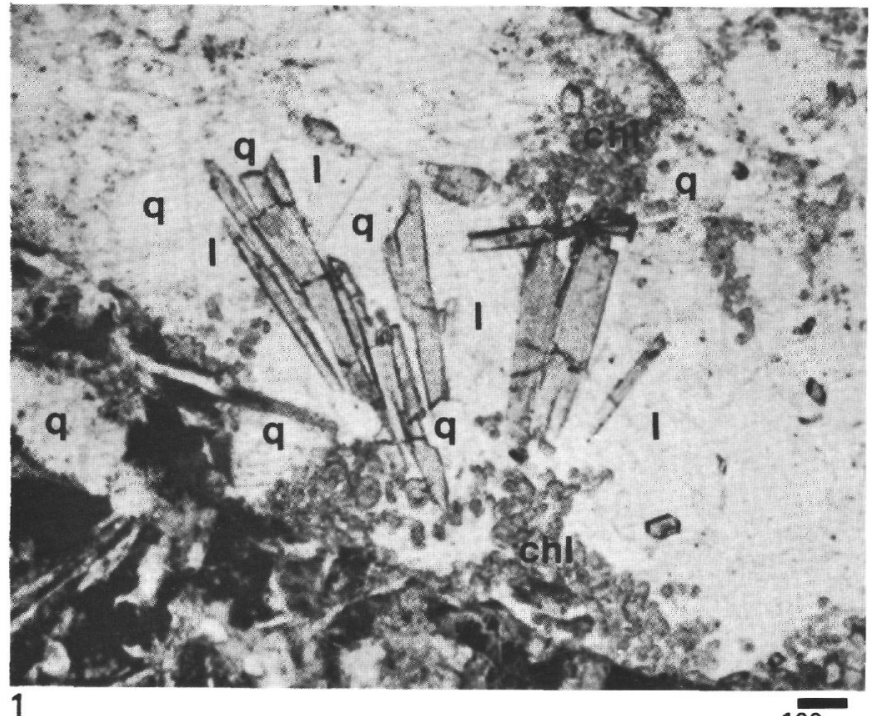

1

$10 \overline{\mu m}$
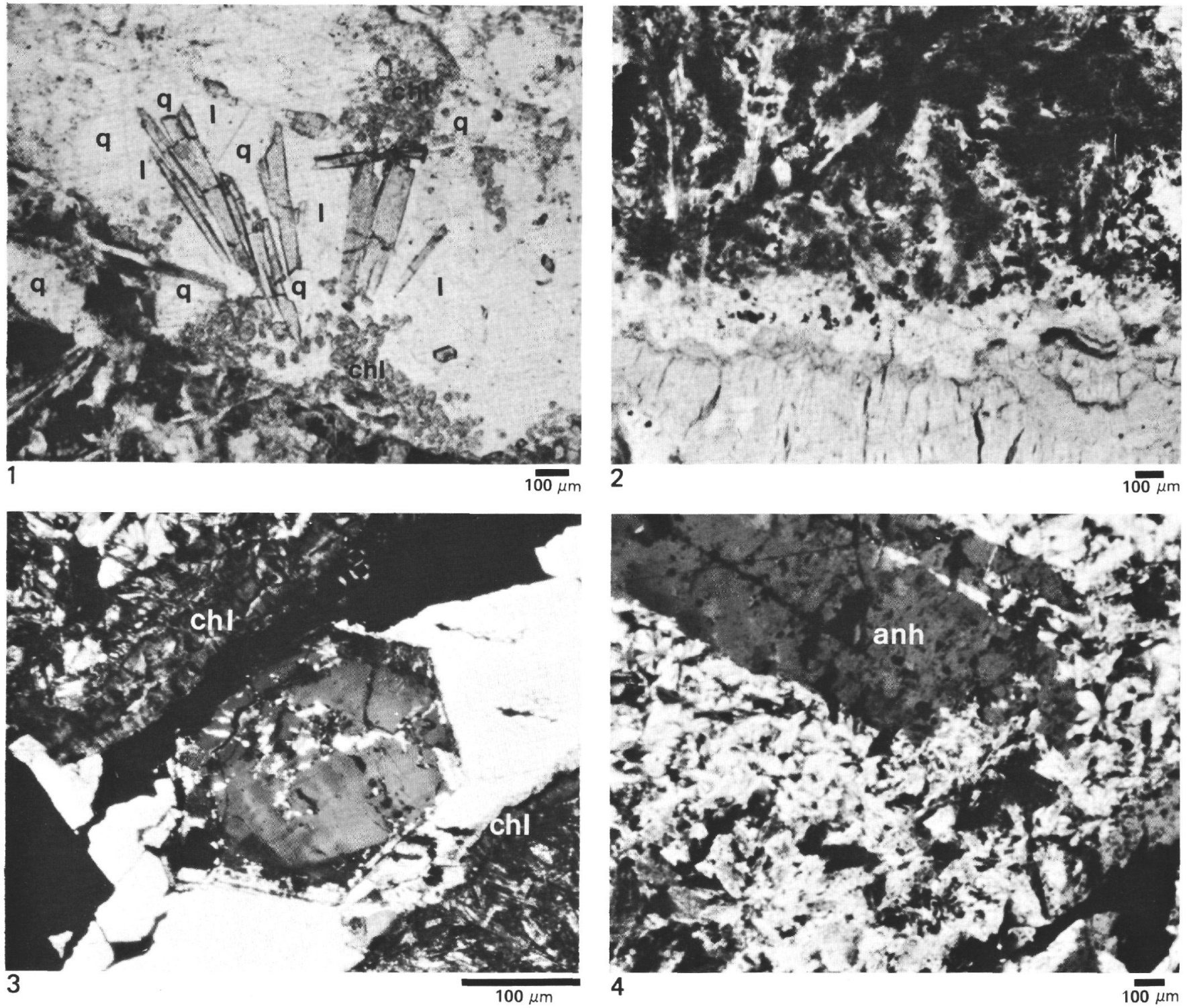

Plate 3. Photomicrographs of vein minerals in Leg 83 basalts. 1. Prismatic epidote (gray) quartz (q), and chlorite (chl) in vein with later laumontite (1). Some epidote crystals are broken and cut by laumontite, and quartz is partly replaced by heulandite (white). Plane light. Sample 504B$100-1,104-108 \mathrm{~cm}$. 2. Silicified wall rock (white) adjacent to Stage 1 clay mineral vein. Clay vein contains fragments of silicified wall rock and quartz (lower left). Plane light. Sample 504B-82-1, 68-73 cm. 3. Vein rimmed with Stage 1 chlorite (chl) contains euhedral Stage 2 quartz (gray) partly replaced by Stage 3 heulandite (white) and surrounded by later calcite (white). Black areas are glue where calcite was lost during polishing. Crossed polars. Sample 504B-80-1, 106-111 cm. 4. Anhydrite (anh) partly replaced by prehnite (fibrous, black and white). Crossed polars. Sample 504B-141-1, 58-61 cm. 

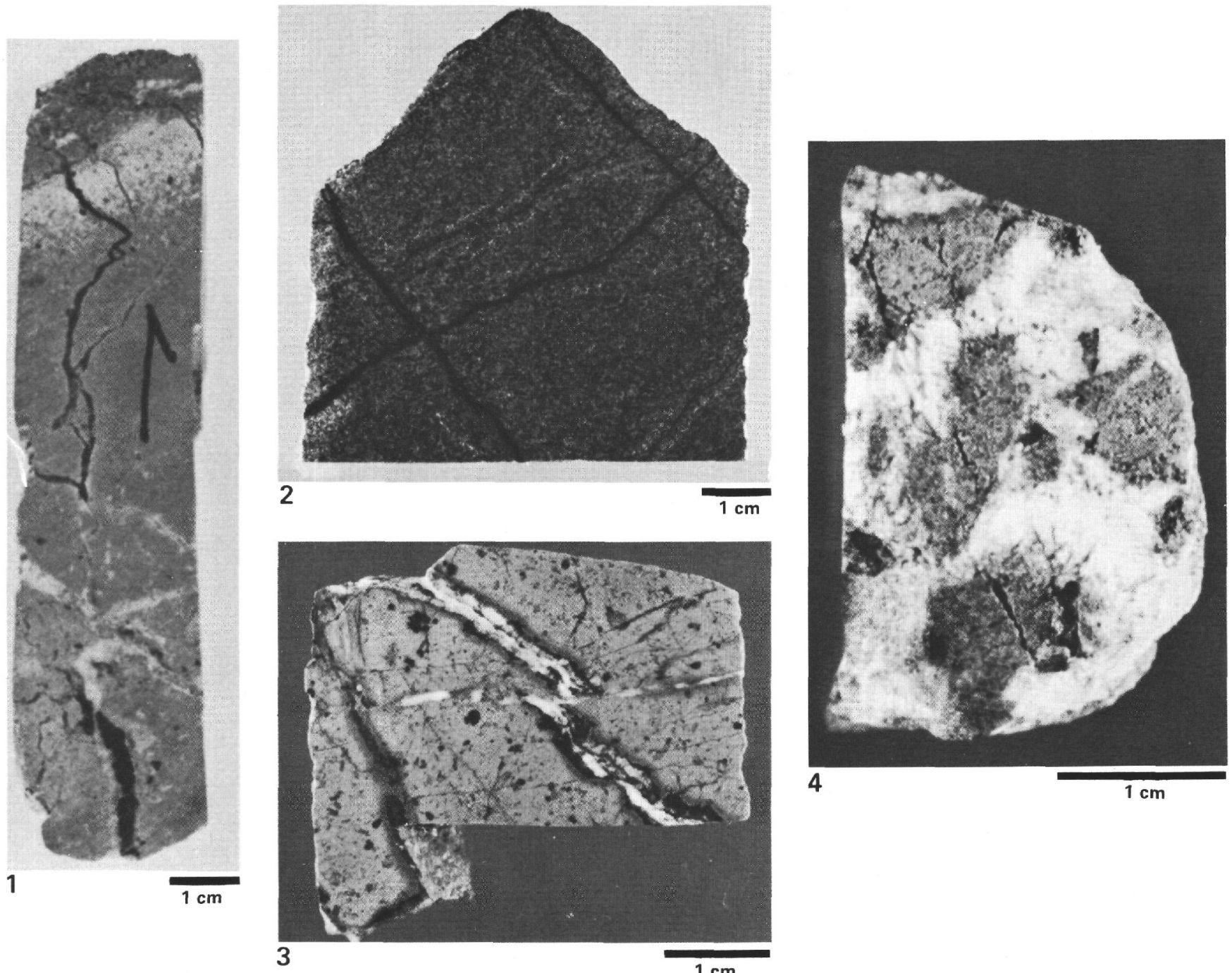

Plate 4. Photographs of hand specimens from the Leg 83 transition zone. 1. Light gray pillow basalt with lighter gray fine-grained pillow rim veins (light gray). Sample 504B-80-3, 124-133 cm. 2. Dark gray massive basalt (dike?). Pyrite is disseminated in the wall rock along cross-cutting clay mineral veins (Type 5, see text). Sample 504B-75-1, 1-4 cm. 3. Light greenish gray pillow basalt illustrating multiple vein fillings. Veins were first filled with clay minerals + actinolite (black), then reopened and filled with epidote and quartz (white), followed by laumontite and heulandite (white). Note second quartz vein offsetting reopened clay mineral veins. Wall rock totally recrystallized to actinolite, albite, chlorite, and sphene in millimeter-sized dark gray zones adjacent to clay mineral veins. Black spots in host rock are clay mineral pseudomorphs after olivine phenocrysts. Sample 504B-90-3, 94-98 cm. 4. Breccia consisting of centimeter-sized basalt fragments cemented by chlorite (black), quartz, laumontite (both white), and acicular epidote (gray). Sample 504B-90-1, 69-72 cm. 

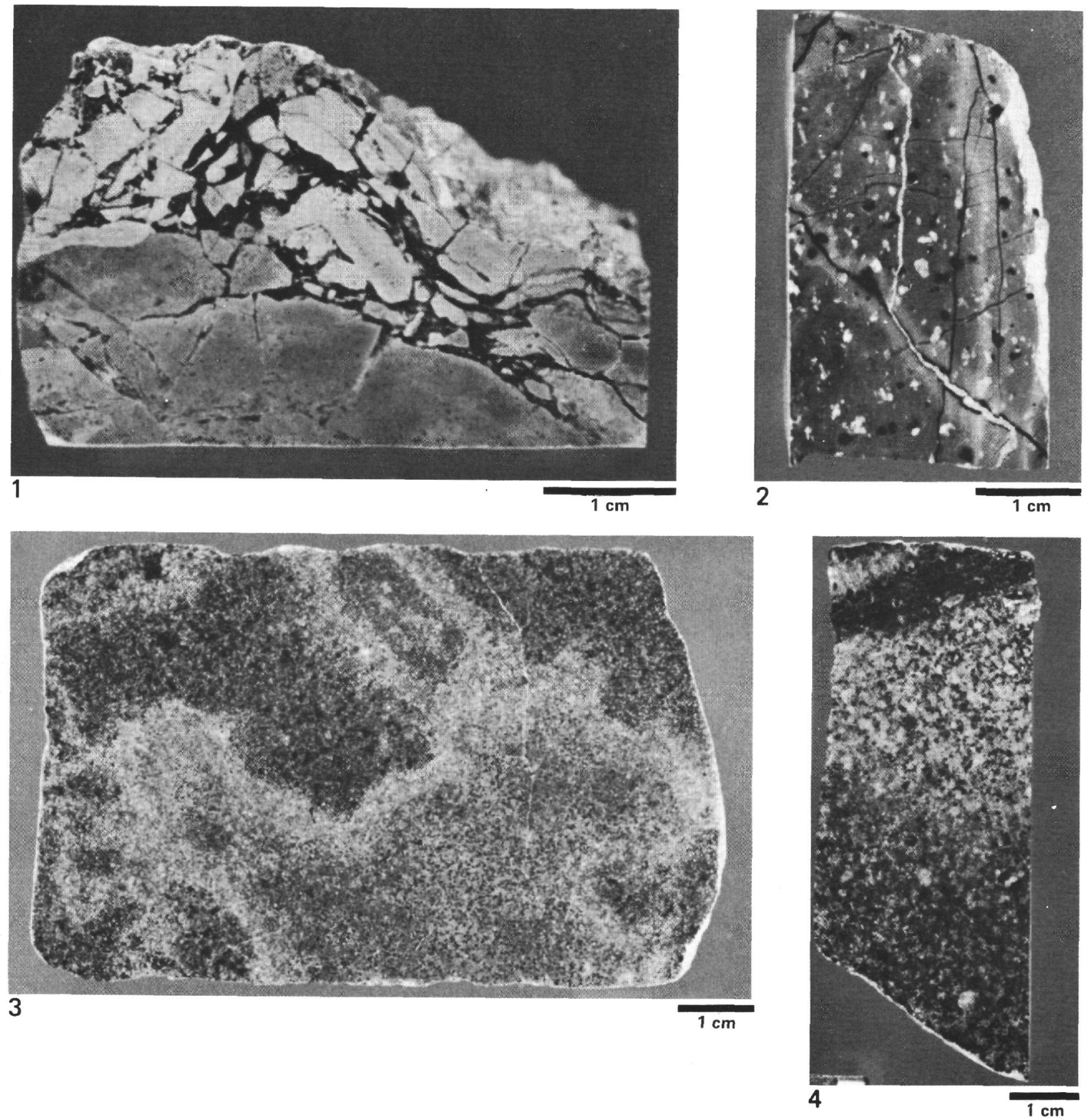

Plate 5. Photographs of hand specimens from the Leg 83 sheeted dike section. 1. Brecciated, fine-grained dike margin cemented by chlorite (black) and zeolites (not visible). Sample 504B-101-1, 134-138 cm. 2. Fine-grained dike fragment from the bottom of the Leg $83 \mathrm{section}$. Basalt is nearly totally recrystallized to actinolite, chlorite, albite, and sphene. Veins are filled with chlorite (black) and cut by laumontite (white). White spots are albitized plagioclase phenocrysts. Sample 504B-141-1, 67-71 cm. 3. Dark gray host rock with irregularly shaped lighter gray zone of extensively recrystallized basalt. Lighter gray area corresponds to a zone of more abundant pore space and/or fine-grained interstitial material (glass?). Sample 504B-133-2, 34-43 cm. 4. Dark gray dike rock with more extensively altered light gray wall-rock zone around millimeter-sized clay mineral vein (Type 2, see text). Basalt is totally recrystallized to chlorite and sphene within about $1 \mathrm{~mm}$ of vein (dark area at top). Sample 504B-104-2, 48-55 cm. 

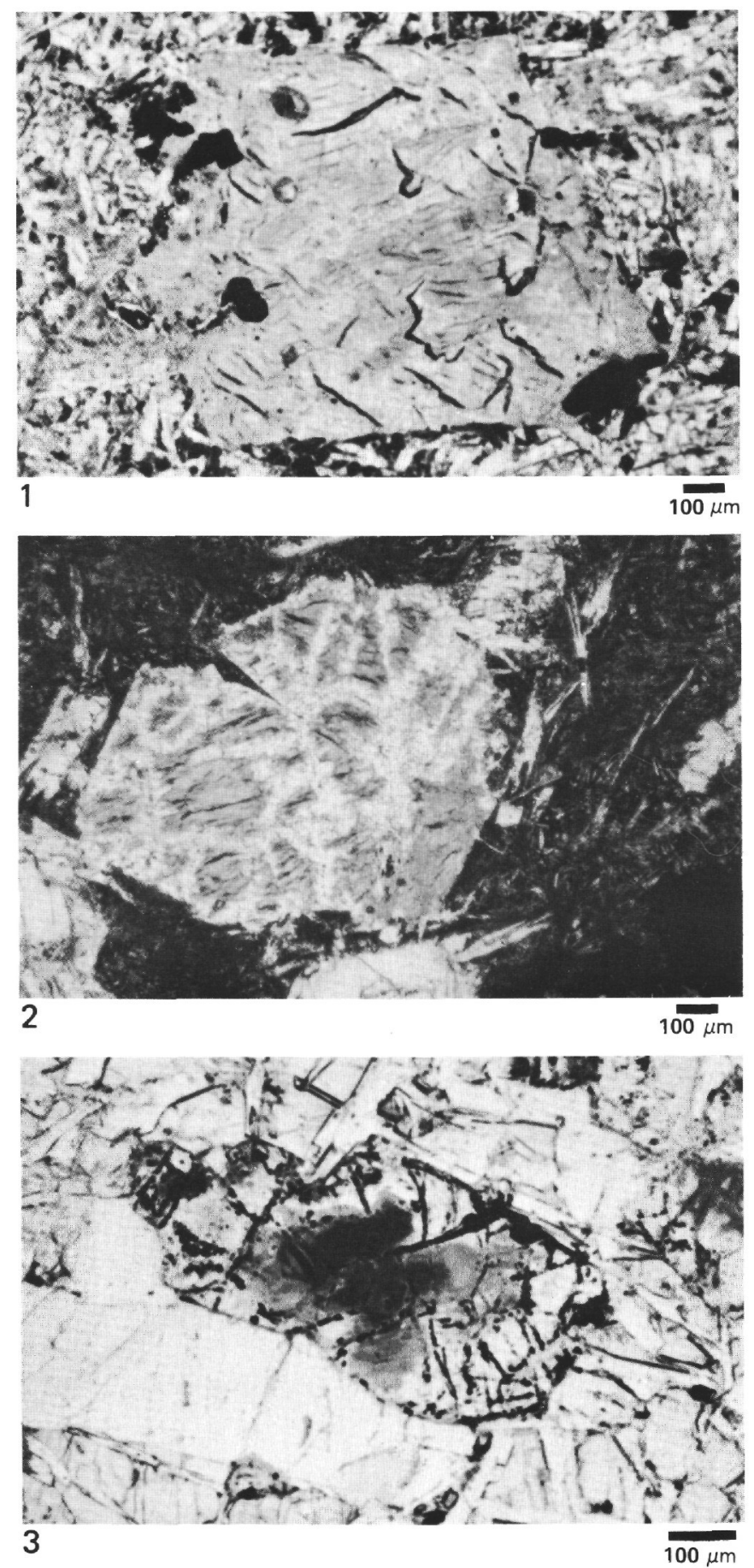

Plate 6. Photomicrographs of olivine replacement products. 1. Olivine phenocryst replaced by Type 1 clay mineral (see text) and pyrite (black). Plane light. Sample 504B-94-1, 132-135 cm. 2. Olivine phenocryst replaced by quartz (white) and Type 2 clay mineral (see text). Plane light. Sample 504B-82-1, 68-72 cm. 3. Olivine phenocryst replaced by talc (white) and magnetite (black) around the outer rim and by Type 5 clay mineral (see text) at center (dark gray). Plane light. Sample 504B-127-1, 109-112 cm. 